\title{
The Best Interest Is the Child: A Historical Philosophy for Modern Issues
}

\author{
Labny R. Silva*
}

\begin{abstract}
A little over a century after the creation of the first juvenile court in America, the states and the federal government continue to try to find an effective and practical solution to juvenile delinquency. Beginning with the "Best Interest of the Child Standard" in 1899, juvenile justice policy has evolved into a mixed bag of philosophies. State statutes littered with "Best Interest" rhetoric, have interestingly resulted in state policies that are retributive in nature and disproportionately affect minority communities. The disconnect between theory and practice is the product of decades of socio-political influence on juvenile justice policy as well as a replacement of the "Best Interest" standard with staunch retributive ideals. This article puts forth a contemporary understanding of "Best Interest," so as to unite theory and practice. This union may provide guidance for more effective policies in the realm of juvenile justice.

America faces a costly and overburdened prison industrial complex that is fed by the juvenile justice system. Transfer provisions seamlessly transport juvenile offenders into adult court for criminal prosecution. Fuveniles adjudicated in adult court face barsher penalties and diminished socio-economic opportunity than juveniles adjudged in juvenile court. While state lawmakers have recently recognized a decrease in violent crime among juveniles overall, many have refrained from advocating policies that promote true "Best Interest" ideals and instead have maintained a focus on law and order. Recent scientific research and psychosocial studies along with the past decade of United

\footnotetext{
* Associate Professor of Law, Indiana University Robert H. McKinney School of Law, LL.M. University of Wisconsin Law School, 2011. My sincerest gratitude to my commentators Kaaryn Gustafson, Carlton Waterhouse, Cheryl Butler, Sarah Jane Foreman, Amy Reichbach, Joel Schuum, Jennifer Drobac and Margaret Ryznar. Many thanks to ClassCrit and the University of Wisconsin Law School as well as Law and Society 2013 where I received a number of helpful and insightful comments. I also owe a significant thanks to my research assistant Cassie Nielson and my most valuable player Julie Davis.
} 
States Supreme Court precedent suggest that policymakers' emphasis on retribution is misguided and anachronistic. Instead, legislators ought to be recognizing the real differences between juveniles and adults namely the "immaturity" of minors as well as their penchant for rehabilitation. This principle is already entrenched in other areas of law such as the minor abortion line of cases.

This article advocates for a return to the "Best Interest of the Child" standard. Calling for an organic view of "Best Interest where contemporary contextual factors may be considered," this article suggests that "Best Interest" calls for a focus on mitigation. This argument builds on Elizabeth S. Scott's and Laurence Steinberg's mitigation theory of juvenile justice. Scott and Steinberg argue that adolescents, because of their biological and psychosocial distinctions, possess a diminished capacity and are thereby less criminally blameworthy. Therefore, they argue, this diminished capacity ought to be recognized in the adult prosecution of juveniles. This article argues that Scott and Steinberg's mitigation paradigm implicitly contains Best Interest principles that may belp guide legislators in fashioning legal tools for which to adjudicate juvenile offenders in adult court.

Beginning with a call for a "presumption of immaturity" in transfer decisions, this essay begins to examine practical solutions within a mitigation paradigm guided by Best Interest principles. Borrowing from minor abortion jurisprudence, it is contended that in those jurisdictions that have established automatic transfer provisions there ought to be a "presumption of immaturity" that the state must overcome prior to commencing an adult prosecution of a juvenile. Moreover, in the actual adjudication of a juvenile in adult court, defenses such as diminished capacity and extreme mental or emotional disturbance ("EMED") may provide a vebicle for the admissibility of psychological and neurological evidence associated with adolescent immaturity and development thereby allowing the fact-finder to consider such evidence in its determination of criminal blameworthiness.

\section{INTRODUCTION}

The "Best Interest of the Child" standard, a theoretical premise deeply embedded in American jurisprudence, is in desperate need of reframing, particularly in the context of juvenile justice administration. While the "Best Interest of the Child" continues to be used by a majority of juvenile courts across the country, the theoretical underpinnings lack coherence and consistency, resulting in many outcomes that 
prove contrary to the "Best Interest of the Child." This results in a number of deleterious issues affecting both the individual child and community.

The larger socioeconomic consequences of a disjointed theoretical base are problematic not only for America's youth but also American taxpayers. The current juvenile justice system feeds the problem of mass incarceration in the United States by channeling a good number of youth into adult prison which thereby fuels the perpetuation of a "ghetto underclass." By revisiting and reformulating the "Best Interest of the Child" standard in a way that addresses the current system as well as the needs of today's youth, policymakers and jurists alike will have guidance in crafting workable and practical solutions to the problem of juvenile crime in their jurisdictions.

The discussion of the problem in juvenile justice administration begins with cost. First, America spends billions of dollars annually detaining and incarcerating youthful offenders. The most recent official national study conducted in 2011 placed 60,500 juveniles in residential programs or correctional facilities. ${ }^{1}$ Approximately half of these youth are non-violent offenders. ${ }^{2} \mathrm{~A}$ disproportionate number are minorities. ${ }^{3}$ In addition, there is a substantial loss in opportunity. This loss relates not only to individual youth but to the youth's family and larger community. This loss can be observed in terms of economic contribution to the family, community, and tax base as well as a reduction in the overall lifetime earning potential of the individual juvenile.

Recent scientific research and psychosocial studies, along with the past decade of United States Supreme Court precedent, suggest that policymakers' emphasis on retribution is misguided and anachronistic. Instead, legislators ought to be recognizing the real differences between juveniles and adults - namely the "immaturity" of minors as well as their penchant for rehabilitation. This principle is already entrenched in other areas of law such as the minor abortion line of cases.

This article advocates for a return to the "Best Interest of the Child" standard. Calling for an organic view of Best Interest where

1. Richard A. Mendel, The Annie Casey Foundation, No Place for Kids: THE CASE FOR REDUCING JUVENILE INCARCERATION 1 (2011).

2. Id.

3. Id. 
contemporary contextual factors may be considered, this article suggests that Best Interest calls for a focus on mitigation. This argument builds on Elizabeth S. Scott's and Laurence Steinberg's mitigation theory of juvenile justice. ${ }^{4}$ Scott and Steinberg argue that adolescents, because of their biological and psychosocial distinctions, possess a diminished capacity and are thereby less criminally blameworthy. ${ }^{5}$ Therefore, they argue, this diminished capacity ought to be recognized in the adult prosecution of juveniles. ${ }^{6}$ This article argues that Scott and Steinberg's mitigation paradigm implicitly contains Best Interest principles that may help guide legislators in fashioning legal tools for which to adjudicate juvenile offenders in adult court. This article explores those possibilities. Beginning with the argument for a "presumption of immaturity" in transfer decisions, this essay begins to examine practical solutions within a mitigation paradigm guided by Best Interest principles. Borrowing from minor abortion jurisprudence, it is contended that in those jurisdictions that have established automatic transfer provisions there ought to be a "presumption of immaturity" that the state must overcome prior to commencing an adult prosecution of a juvenile. Moreover, in the actual adjudication of a juvenile in adult court, defenses such as diminished capacity and extreme mental or emotional disturbance ("EMED") may provide a vehicle for the admissibility of psychological and neurological evidence associated with adolescent immaturity and development, thereby allowing the factfinder to consider such evidence in its determination of criminal blameworthiness.

The first half of this article is descriptive. Part II examines the historical development of juvenile courts, bringing with it the theoretical understanding of the "Best Interest of the Child" standard in juvenile justice administration. Part III describes the current state of affairs in juvenile justice administration. By identifying problems within the system, including dilemmas with incarceration, transfer to adult court, and the disproportionate impact on minority communities, one may (2003).

4. Elizabeth S. Scott \& Laurence Steinberg, Blaming Youth, 81 Tex. L. Rev. 799, 838

5. Id.

6. Id. 
contemplate desired outcomes. The second half of the article concentrates on reframing the "Best Interest of the Child" standard through the mitigation paradigm advanced by Scott and Steinberg. Part IV discusses mitigation as a portal to preserving Best Interest ideals as well as evidence that tends to support the framework. This section includes a brief discussion of recent brain science and psychosocial research that demonstrates real biological and social differences between minors and adults. This section also discusses recent United State Supreme Court jurisprudence on the issue of adolescent development. Part V lays out presumptions and defenses that may be reconfigured for use in the adult prosecution of juveniles. These include the establishment of an already recognized principle, the "presumption of immaturity," as well as the traditional defenses of diminished capacity and extreme emotional disturbance. Part VI concludes with a summary of the main points as well as thoughts for next steps in the development of an effective American juvenile justice system where the "Best Interest of the Child" returns to center stage.

\section{JUVENILE JUSTICE IN AMERICA}

The American colonies conveyed to themselves the powers held by the English Crown concerning the welfare of juveniles. ${ }^{7}$ English common law bequeathed the right and responsibility of protecting those persons incapable of protecting themselves to the Crown. ${ }^{8}$ The general protection of children was bestowed upon the landed aristocracy for the purpose of securing profits for the Crown. ${ }^{9}$ The colonies retained this practice but extended these general protections beyond the landed aristocracy. ${ }^{10}$

Early common law generally treated children under the age of seven years old as "incapable of possessing criminal intent." ${ }^{11}$ Any child

7. See Douglas R. Rendlemen, Parens Patriae: From Chancery to the Juvenile Court, in Juvenile Justice and Philosophy: Readings, Cases and COMment 58, 59-60 (Frederic L. Fraust \& Paul J. Brantingham eds., 2d ed. 1979).

8. Id.

9. Id.

10. C. Antoinette Clarke, The Baby and the Bathwater: Adolescent Offending and Punitive fuvenile fustice Reform, 53 U. KAN. L. REV. 659, 662 (2005).

11. In re Gault, 387 U.S. 1, 16 (1967). 
older than seven was treated and punished like an adult offender. ${ }^{12}$ While youths over the age of seven could be treated and punished like their adult counterparts, they were denied a number of rights granted to adult offenders. ${ }^{13}$ Throughout early American history, children were understood to be "legally incompetent." ${ }^{14}$ In most criminal matters, children under the age of seven could assert "infancy" as a defense while older children seven to fourteen were subject to a rebuttable presumption of lack of capacity. ${ }^{15}$ Youths were subject to adult criminal prosecution and if convicted imprisoned in adult facilities. ${ }^{16}$ With courts rarely interfering with familial and educational pursuits, parents and schools were permitted to use their choice of disciplinary approaches to regulate misbehavior. ${ }^{17}$

The Industrial Revolution changed the configuration of the family structure as well as the role of the family in American society. This presented substantial challenges with regard to children and the interaction of the state with the modernized family. States were forced to deal with wayward children and those youths considered inveterate. ${ }^{18}$ Toward the end of the nineteenth century, moralist proponents, known as "gentlemen reformers," created juvenile correctional facilities for youthful offenders. ${ }^{19}$ The gentlemen reformers were largely white Anglo-Saxon Protestants, guided by Enlightenment philosophy and determined to eliminate pauperism. ${ }^{20}$ Such delinquents were thought to be "a product of their bad environment and the failure of

12. $I d$.

13. Id. at 14 .

14. Clarke, supra note10, at 12.

15. Barry C. Feld, Fuvenile (In)fustice and the Criminal Court Alternative, 38 CRIME \& DELINQ. 403, 404 (1993).

16. Gerald F. Glynn, Arkansas' Missed Opportunity for Rehabilitation: Sending Children to Adult Courts, 20 U. ARK. LiTTLE RoCK L. Rev. 77, 80 (1997).

17. $I d$.

18. CARL N. Degler, AT OdDS: WOMEN AND THE FAMiLy IN AMERICA From THE Revolution to the Present 178-209 (1980); Barry C. Feld, The fuvenile Court Meets the Principle of Offense: Punishment, Treatment, and the Difference It Makes, 68 B.U. L. REV. 821, 821 23 (1988).

19. $I d$.

20. See generally SANFORD J. Fox, THE EARLy History OF THE COURT 16-29 (1996). 
the family." ${ }^{21}$ This ideology was soon to be overshadowed by the Progressive reformers, a group largely credited with the creation of the first juvenile court in $1899 .{ }^{22}$

Prior to 1899, early Progressive reformers in Massachusetts, Pennsylvania, and New York established Houses of Refuge. ${ }^{23}$ The purpose of these houses was to save children from crime and imprisonment. ${ }^{24}$ The focus was on protecting children rather than punishing the youth for engaging in criminal behavior. ${ }^{25}$ Two principal concerns guided these reformers: the malleability of children and the idea that the child's environment was the primary cause of delinquent conduct. ${ }^{26}$ Delinquency was considered an outgrowth of immorality and poverty. ${ }^{27}$ With this, Progressive reformers initiated a series of developments in the administration of young offenders centering on the child and the best interest of that child. ${ }^{28}$ The ideas of the Progressives developed into the theoretical understanding of the "Best Interest" standard that we know today. Justice Fortas described Progressive ideology with regard to child offenders as considering "[w]hat is he, how has he become what he is, what had best be done in his interest and in the interest of the state to save him from a downward career." 29 It was of no consequence to determine the actual "guilt" of the juvenile offender. ${ }^{30}$ Instead, the focus was on treating the child with the goal of assisting in the reconstruction and rehabilitation of the child's life. ${ }^{31}$

21. Feld, supra note 18.

22. Fox, supra note 20, at 29; LeWIS P. TODD \& MERLE E. CURTI, Rise OF THE AMERICAN NATION 536 (1986).

23. BarRy C. Feld, Bad KidS: RaCE and the Transformation of THE JUVENILE COURT 54 (1999); John R. Sutton, Social Structure, Institution, and the Legal Status of Children in the United States, 88 AM. J. Soc. 915, 915-19 (1983).

24. FELD, supra note 23.

25. Clarke, supra note 10 , at 12 .

26. Eric K. Klein, Comment, Dennis the Menace or Billy the Kid: An Analysis of the Role of Transfer to Criminal Court in Fuvenile fustice, 35 AM. CRIM. L. REV. 371, 376 (1998).

27. Kelly Keimig Elsea, The fuvenile Crime Debate: Rehabilitation, Punishment, or Prevention, 5 KAN. J.L. \& PUB. POL'Y 135, 137 (1995).

28. In re Gault, 387 U.S. 1, 15 (1967).

29. $I d$.

30. TODD \& CURTI, supra note 2222, at 536.

31. In re Gault, 387 U.S. at 15. 
The Progressive priority was clinical evaluation followed by treatment and management of the child. ${ }^{32}$

The establishment of the Houses of Refuge brought with it constitutional due process challenges. There was a clear absence of formal process in the placement of children in these facilities. Moreover, the courts appeared to lack recognized legal authority to do so. In the midnineteenth century, courts across the country began to face this issue head on. In Ex parte Crouse, the father of a teenage girl constitutionally challenged her commitment to a Pennsylvania house on the basis of a trial by jury violation. ${ }^{33}$ The basis of the complaint was a violation of the trial by jury guarantee. ${ }^{34}$ In finding the commitment constitutional, the Pennsylvania Supreme Court asserted that such commitment fell within the parens patria of the state. ${ }^{35}$ The objective of the doctrine was to rehabilitate and reform children as opposed to punishing the wayward youth. ${ }^{36}$ With this, the court held that due process does not prohibit a state from imposing institutional restraint on a child for the child's welfare. ${ }^{37}$ The doctrine was again invoked by the Massachusetts Supreme Judicial Court in $1886 .{ }^{38}$ In Farnham v. Pierce, the Massachusetts Supreme Judicial Court permitted the commitment of a child without a hearing to make a commitment determination. ${ }^{39}$ The court cited parens patriae as the rationale underlying the state's power to place the child. ${ }^{40}$ The principle underlying these early American cases is the idea that the state may assume control of a child for the purposes of protecting the welfare of the child and not for purposes of criminal adjudication and punishment. ${ }^{41}$ These cases stimulated the establishment of a separate juvenile court system with Ex parte Crouse serving as the precedential justification for upholding juvenile commitments. ${ }^{42}$

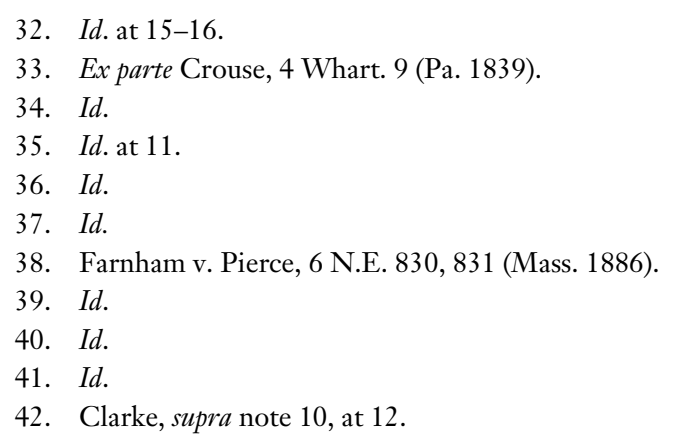


The first officially recognized juvenile court was established in Cook County, Illinois in $1899 .{ }^{43}$ The jurisdictional arm of the court applied to children under the age of sixteen years old. ${ }^{44}$ By the 1940 s, juvenile court systems were created in all fifty states. ${ }^{45}$ From the beginning, the principal consideration of the juvenile courts was the welfare of the child. ${ }^{46}$ Juvenile courts utilized indeterminate processes that integrated principles of psychology and social work in their evaluation of children. With this, they developed specific and individualistic treatment plans to meet the child's needs. ${ }^{47}$ This required exercising vast discretion in order to develop appropriate remedies that would adequately address the child's issues. ${ }^{48}$

In the 1960s, American courts began to systematically develop the doctrine of parens patriae understanding that wise adults ought to make decisions in the best interest of minor children. ${ }^{49}$ In the court's formulation of the "Best Interest," both the child's physical and psychosocial well-being was paramount. ${ }^{50}$ Tension existed however, between providing children with individual treatment and the inundation of juvenile offenders into the juvenile court system. ${ }^{51}$ The sheer volume of cases in juvenile courts began to overburden a juvenile justice system that had been in place since the early $1900 \mathrm{~s}^{52} \mathrm{With}$ individual treatment no longer a viable option, courts chose between one of two

43. Anthony M. Platt, The Child Savers: The Invention of Delinguency 101-36 (2d ed. 1977).

44. Laureen D'Ambra, A Legal Response to fuvenile Crime: Why Waiver of fuvenile Offenders Is Not a Panacea, 2 Roger Williams U. L. ReV. 277, 280 (1997).

45. Adam D. Kamenstein, The Inner-Morality of fuvenile fustice: The Case of Consistency and Legality, 18 CARDOZO L. REV. 2105, 2111 (1997).

46. Marygold S. Melli, fuvenile fustice Reform in Context, 1996 WIS. L. REV. 375, 378 (1996).

47. Platt, supra note 43 , at 43-47.

48. F. Faust \& P. Brantingham, The Invention of the Juvenile Court, in Juvenile Justice Philosophy 550-57 (1974),

49. Barry C. Feld, The Transformation of the Fuvenile Court, 75 MINN. L. REv. 691, 695 (1996).

50. Gilbert v. Gilbert, No. 093459, 1996 Conn. Super. Ct. LEXIS 2153 (Aug. 16, 1996).

51. Jennifer O'Connor \& Lucinda K. Treat, Note, Getting Smart About Getting Tough: Fuvenile fustice and the Possibility of Progressive Reform, 33 AM. CRIM. L. REV. 1299, 1303 (1996).

52. Id. 
courses: sending juveniles to correctional facilities or meting out lenient sanctions. ${ }^{53}$ The rulings of the courts slowly began to abandon individualized treatment and proportionality in juvenile punishment and instead began to resemble adult criminal courts with penal sentences justified with parens patriae. ${ }^{54}$ With the transformation of the juvenile court system, the need developed for procedural protections to ensure fairness in processes that may potentially have deprived juveniles of their freedom. Such processes began to take shape with a number of United States Supreme Court cases in the 1960s. Beginning with Kent v. United States, the Court set in motion the solidification of juvenile court as a criminal court for children by requiring constitutional criminal procedural protections for juveniles, including the right to counsel, the right to confront and cross-examine witness, the privilege against self-incrimination, and the right to notice of the charges. ${ }^{55} \mathrm{Ex}-$ plicitly condemning the doctrine of parens patriae in In re Gault, the Court asserted that "unbridled discretion, however benevolently motivated, is frequently a poor substitute for principle and procedure." Per the Court, children "receive[d] the worst of both worlds . . . he gets neither the protections accorded to adults nor the solicitous care and regenerative treatment postulated for children. ${ }^{.57}$

Chronologically coinciding with the transformation of the juvenile court, America itself experienced a social revolution. The 1960s brought with it social movement. The civil rights movement and the Vietnam War worked in sync to create a ripe political environment for social change. The Great Migration of Black America from the South to urban areas changed the socio-political dynamic of American urban areas, with the result of white flight and a concentration of many poor black Americans in one geographic area. ${ }^{58}$ The riots in Watts, Detroit, and other areas of the country painted a stark picture of black violence and called into question black grievances against government that were

53. O'Connor \& Treat, supra note 51.

54. Id. at $1305-07$.

55. Kent v. United States, 383 U.S. 541 (1966).

56. In re Gault, 387 U.S. 1, 18 (1967).

57. Kent, 383 U.S. at 556.

58. David Garland, The Culture Of Control: Crime and Social Order in CONTEMPORARY SOCIETY 84 (2001). 
brought to the forefront during the civil rights movement. ${ }^{59}$ Conservative legislators seized the opportunity to blame social welfare programming for rising crime rates for which they received substantial electoral gains.$^{60}$ Appealing to white voters' racial animus, Conservatives pushed an agenda calling for personal responsibility and penal policies that were tough on crime. ${ }^{61}$ For Lemann, "the government's response to [black] migration provided the conservative movement with many of its issues." 62 This included juvenile courts.

The 1970s were characterized by both a practical and ideological shift. The crime rate of juveniles appeared to explode as the baby boomers reached adolescence. ${ }^{63}$ The escalation of crime was most apparent in the inner cities, which were primarily black areas. ${ }^{64}$ Liberals and conservatives alike endorsed retributive penal polices and determinate sentencing schemes. ${ }^{65}$ Liberals asserted that indeterminate sentencing schemes produced egregious racial disparity while conservatives advocated for harsher criminal sentences. ${ }^{66}$ Tough on crime rhetoric produced statutes and regulations permitting punitive sentences for juvenile offenders. ${ }^{67}$ These laws underscored the juvenile's offense while de-emphasizing the Best Interest of the Child and parens patriae. With this, states began to enact transfer/waiver statutes thereby permitting juveniles to be transferred to adult court for criminal prosecution with relative ease. ${ }^{68}$ Today, all fifty states permit some form of transfer. ${ }^{69}$ At

59. Id. at 97. See generally Nicholas Lemann, The Promised Land: The Great BLACK Migration AND How IT CHANGED AMERICA (1991).

60. Lucas A. Powe, Jr., The Warren Court AND American Politics 495 (2000).

61. LEMANN, supra note 59, at 200.

62. Id.

63. Franklin E. Zimrig \& Gordon HaWkins, Crime Is Not The Problem: LETHAL ViOLENCE IN AMERICA 66 (1997).

64. Francis T. Cullen \& Karen E. Gilbert, REAFFiming REahabilitation 39-40 (1982); Michael TONRY, MALign NEgLECT 94-95 (1995).

65. Michael Tonry, Sentencing Matters 6-12 (1996); Barry C. Feld, The fuvenile Court Meets the Principle of Offense: Legislatives Changes in Fuvenile Waiver Statutes, 78 CRIM. L. \& CRIMINOLOGY 471, 483-87(1987).

66. TONRY, MALign NegleCt, supra note 64, at 94-95.

67. The Real War on Crime: The Report of the National Criminal Justice COMMISSION 3 (Steven R. Donziger ed., 1996).

68. Hunter Hurst III, Crime Scene: Treating Fuveniles as Adults, Trial, July 1997, at 34.

69. Kelly M. Angell, Note, The Regressive Movement: When fuvenile Offenders Are Treated as Adults, Nobody Wins, 14 S. CAL. INTERDISC. L.J. 125, 127 (2004). 
a national level, the 1970s ushered in the establishment of the Juvenile Justice and Delinquency Prevention Act. ${ }^{70}$ The Act emphasized four core purposes to which juvenile justice administration was encouraged to focus: deinstitutionalization of status offenders (truants, curfew violators), separation of juveniles from adults in jail, disallowance of the placement of youth in adult facilities, and decrease in minority overrepresentation in the juvenile system. ${ }^{71}$

The War on Drugs was a catalyst for the enactment of determinate sentencing policies and harsh sentences for drug offenders. The introduction of crack cocaine into urban areas in the 1980s birthed an era of both devastation and violence in black neighborhoods. ${ }^{72}$ The drug industry produced youths armed for their own protection with the purpose of protecting drug profits. ${ }^{73}$ Between 1986 and 1993 the juvenile murder rate increased 278 percent for black youth while it increased forty percent for their white counterparts. ${ }^{74}$ During the same time period, gun homicides quadrupled for juveniles ${ }^{75}$ and the myth of the "Superpredator" was unleashed. ${ }^{76}$ The media's portrayal of urban black males further exacerbated anxieties calling for harsher punishment for juvenile offenders while simultaneously aggravating an already existing racial disparity in arrest rates for juvenile crime. ${ }^{77}$ The Juvenile Justice and Delinquency Prevention Act enacted in the early 1970's was modified to include minimum detention requirements and

70. The Juvenile Justice and Delinquency Prevention ACt of 1974, 88 Stat. 1109 (1974).

71. Id.; Heather Hojnacki, Graham v. Florida: How the Supreme Court's Rationale Encourages Reform of the fuvenile fustice System through Alternative Dispute Resolution Strategies, 12 PEPP. DiSP. RESOL. L. J. 135, 137-38 (2012).

72. Philip J. Cook \& John H. Laub, The Unprecedented Epidemic in Youth Violence, 25 CRIME \& JUST. 27, 53-54 (1998).

73. Alfred Blumstein, Youth Violence, Guns, and the Illicit-Drug Industry, 86 J. CRIM. \& CRIMinOlOGY 10, 39 (1995).

74. Melissa Sickmund, Howard N. SNYdeR \& EileEn Poe-Yamagata, U.S. DeP'T OF JUSTICE, JUVENILE OFFENDERS AND VICTIM: 1997 UPDATE ON VIOLENCE 13 (1997).

75. Franklin E. Zimring, Kids, Guns, and Homicide: Policy Notes on an Age-Specific Epidemic, 59 LAW \& CONTEMP. PROBS. 25, 28 (1996).

76. See, e.g., Office of Juvenile fustice \& Delinquency Prevention, U.S. Dep't of Justice, 1999 National Report Series, Juvenile Justice Bulletin: Challenging the Myths 2 (Feb. 2000), available at http://www.ojjdp.gov.

77. Marc Mauer, RaCe To InCarCerate 13 (1999). 
an escape hatch provision in the statute. ${ }^{78}$ This provision permitted the criminal prosecution of juveniles for weapons and violent offenses. ${ }^{79}$

Two decades later, America is experiencing the aftershocks of the War on Drugs. The volume of cases in juvenile courts has considerably increased "without a corresponding increase in resources." 80 The effects of these policies have resulted in 60,500 youths in correctional facilities or other residential programs. ${ }^{81}$ Over sixty percent of those in custody are male youth of color. ${ }^{82}$ The United States Department of Justice's Office of Juvenile Justice and Delinquency Prevention (“OJJDP") recently reported that in some jurisdictions fifty percent of juveniles released from detention are rearrested within three years or less of release. ${ }^{83}$ Legislators have enacted a number of statutes facilitating streamlined transfers of juveniles from juvenile court to adult court. ${ }^{84}$ Most notably, state provisions include mechanisms that circumvent "individualized treatment" and provide categorical offensebased jurisdictional requirements thereby bypassing the juvenile system altogether. ${ }^{85}$ Despite the significant changes in juvenile justice administration, most states have not completely abandoned the rehabilitative ideal encapsulated in the Best Interest of the Child paradigm. ${ }^{86}$

Most of the Best Interest principles guiding the Progressive Reformers remain important today. First, it is important to recognize that minors are distinct from adults. The law has a history of restraining the type of activities and freedoms to which juveniles may actively engage based solely on their age. Juveniles are not permitted to enter into contracts, vote, enter the armed forces, or buy alcohol. It is a legal in-

78. Hojnacki, supra note 71, at 139.

79. Id.

80. Edmund F. McGarrell, Restorative fustice Conferences as an Early Response to Young Offenders, Juv. Just. Bull. (Office of Juvenile Justice \& Delinquency Prevention, Wash., D.C.), Aug. 2001, at 2, available at http://www.d.umn.edu/ jmaahs/Vita\%20and\%20pubs/Delinquency\%20and\%20Juvenile\%20Justice/restore1.pdf.

81. SICKMUND, ET AL., supra note 74 , at 200.

82. Id. at 209.

83. Id. at 234.

84. Mark Soler, Fuvenile Fustice in the Next Century: Programs or Politics, 10 CRIM. JUST. 27 (1996).

85. Id.

86. Craig Hemmens, Eric J. Fritsch \& Tory J. Caeti, The Rhetoric of Fuvenile Fustice Reform, 18 QLR 661, 677 (1999). 
consistency to allow a juvenile to be adjudicated in adult court and sentenced to adult prison, without granting corollary rights to juveniles. Second, Best Interest ideals value the malleability of minors. It recognizes that juveniles are in psychosocial and biological transition and are therefore capable of changing their behaviors. Finally, Best Interest promotes clinical and individualized treatment. It seeks to review instances of juvenile delinquency on a case-by-case basis and create a special treatment plan for that specific minor. Best Interest principles frown upon juvenile transfer to adult court because in the case of children there is still hope for change. While juvenile courts are overburdened with the number of cases on the docket, it is important to recognize the long-term consequences of ignoring individual juvenile issues.

\section{CONTEMPORARY ISSUES}

Transfers to adult court, recidivism, and disparate impact are the hallmark of today's juvenile justice system. The contextual and theoretical changes that influenced the transformation of legal and institutional principles have led to a schizophrenic ideological understanding of juvenile justice today. To pinpoint one ideological principle that represents juvenile justice administration in America today is far from an easy task. While the purpose clauses of juvenile codes may give scholars and advocates an implicit hint, the codes themselves are comprised of a "mixed bag" of theoretical underpinnings that include both "Best Interest" and retributive ideals. ${ }^{87} \mathrm{It}$ is from these muddy waters that an in-depth assessment of contemporary problems is examined. Focusing specifically on transfer, imprisonment, recidivism, and disproportionate impact, this section aims to present a portrait of the current state of affairs.

\section{A. Transfer}

Since its inception, the juvenile justice system in America has sustained statutory and regulatory provisions permitting transfer of

87. Linda F. Giardino, Statutory Rhetoric: The Reality Bebind Fuvenile Fustice Policies in America, 5 J.L. \& POL'Y 223, 231-36 (1996). 
youths from juvenile court to adult criminal court. ${ }^{88}$ Transfer was traditionally reserved for the most extreme juvenile crimes and older youth. ${ }^{89}$ Approximately, 200,000 juveniles are transferred to adult court each year. ${ }^{90}$ Today, transfer provisions capture thousands of juveniles in the form of categorical offense based statutes that mandate transfer or through largely unreviewable prosecutorial decisions. Once a juvenile is transferred to adult court, most jurisdictions require that he be prosecuted in adult court for any future offenses. ${ }^{91}$

The current trend in transfer decisions substantially diverges from the original theoretical principles of "Best Interest." 92 "Best Interest" considerations have virtually disappeared from transfer determinations as most "decisions" to transfer are mandatory or statutorily required..$^{93}$ Individualized "treatment plans" and clinical evaluations have dissipated. Moreover, the understanding that juveniles are distinct from adults and ought to be treated differently seems to have disappeared from discussions of transfer altogether.

\section{Methods of transfer}

Juveniles are commonly transferred to adult criminal court in one of four ways: judicial waiver, statutory exclusion, prosecutorial transfers, and blended sentence. ${ }^{94}$ Judicial waiver grants juvenile judges the authority to waive jurisdiction and transfer the case to adult court for criminal prosecution. ${ }^{95}$ A number of statutes enumerate factors to be taken into consideration by juvenile court judges. ${ }^{96}$ Most states still

88. See Francis Barry McCarthy, The Serious Offender and fuvenile Court Reform: The Case for Prosecutorial Waiver of fuvenile Court furisdiction, 38 ST. LOUIS U. L.J. 629, 642-43 (1994).

89. Id.

90. Laurence Steinberg, Fuveniles on Trial: MacArthur Foundation Study Calls Competency into Question, 18 CRIM. JUST. 20, 21 (2003).

91. G. Larry Mays \& Rick Ruddell, Do the Crime, Do the Time: Juvenile CRIMINALS AND AdUlt Justice IN THE AMERICAN COURT SYSTEM 10 (2012).

92. Lisa A. Cintron, Comment, Rehabilitating the fuvenile Court System: Limiting fuvenile Transfers to Adult Court, 90 NW. U. L. REV. 1254, 1271 (1995).

93. Id.

94. Fustice or Vengeance: How Young Is Too Young for A Child to Be Tried And Punished as an Adult?, 34 TeX. TECH. L. REV. 159, 168-72 (2002-2003).

95. Melissa Sickmund, ET Al., U.S. DePt. OF Just., OfFice OF JuV. Just. AND Deling. Prevention: How Juveniles Get to Criminal Court, OJJDP UPDATE ON STATISTICS BULLETIN (1994).

96. Kent v. United States, 383 U.S. 541, 565-68 (1996) (Appendix to Opinion of the 
permit judges to waive jurisdiction based on an assessment of the child's "amenability to treatment" and/or "dangerousness." ${ }^{97}$ With this, judges review categorical factors such as the gravity of the offense, the circumstances of the offense, prior record, likelihood of rehabilitation, maturity, and home environment. ${ }^{98}$ Because of the subjectivity of the fundamental issues, courts tend to interpret and ultimately apply transfer statutes inconsistently. ${ }^{99}$

Statutory exclusions or statutory waivers provide no discretion for judges or prosecutors in transfer cases. ${ }^{100}$ Such statutes require transfer for certain offenses while others provide an upper age limit for juvenile court jurisdiction. ${ }^{101}$ This is the most utilized form of transfer today; with the Department of Justice reporting that 41.6 percent of juvenile transfers are achieved using this method. ${ }^{102}$

Prosecutorial transfers give prosecutors discretion to file cases in either juvenile or adult court. ${ }^{103}$ This method is known as prosecutorial waiver or "direct file." ${ }^{104}$ Discretion is non-appealable in some states. ${ }^{105}$ This authority, however, is not absolute. ${ }^{106}$ Prosecutors are generally limited by age and specific offenses. ${ }^{107}$ Nevertheless, without formal parameters, the decision to transfer is largely based on subjective considerations such as the area where the defendant resides and the gravity of the offense. ${ }^{108}$

Court).

97. See Barry C. Feld, Violent Youth and Public Policy: A Case Study of fuvenile fustice Law Reform, 79 MINN. L. REV. 965, 1006 (1995).

98. Kent, 383 U.S. at $565-68$.

99. Feld, supra note 97, at 1010.

100. Catherine R. Guttman, Note, Listen to the Children: The Decision to Transfer Fuveniles to Adult Court, 30 HaRv. C.R.-C.L. L. REv. 507, 521-22 (1995).

101. Id.

102. Gerard A. Rainville \& Steven K. Smith, U.S. DeP’T of Justice, Juvenile FELONY DEFENDANTS IN CRIMINAL COURTS 2 (2003).

103. Barbara J. Valliere, Note, The Transfer of Juvenile Offenders to Adult Courts in Massachusetts: Reevaluating the Rehabilitative Ideal, 20 SUFFOLK U. L. REV. 989, 996 (1986).

104. Brian G. Sellers \& Bruce Arrigo, Adolescent Transfer, Developmental Maturity, and Adjudicative Competence: An Ethical and fustice Policy Inquiry, 99 J. CRIM. L. \& CRIMINOLOGY 435, 442 (2009).

105. Valliere, supra note 103.

106. SiCKMUND, supra note 95 , at 1 .

107. Id.

108. Barry C. Feld, fuvenile Transfer, 3 CRIMINOLOGY \& PUB. POL'Y 599, 601 (2004). 
The blended sentence provides overlap between the juvenile system and adult court. These sentences involve meting out a juvenile punishment with an adult criminal sentence suspended. ${ }^{109}$ So long as the juvenile complies and completes the juvenile sanction, he will not be incarcerated. However, if the juvenile fails to comply with the court-ordered juvenile sanction, he will receive the adult sentence.

\section{The courts and application}

In the 1960's and 1970's the most common transfer strategy was judicial waiver. With this method, juvenile court judges used their discretion to determine whether transfer to adult court was warranted after a hearing was held. During the hearing, the court examined evidence concerning a youth's amenability to treatment and any potential threats the juvenile posed to society. A decision to transfer to adult court was primarily based on the juvenile's criminal history and the seriousness of the crime. ${ }^{110}$

a. Kent v. United States. The United States Supreme Court reviewed judicial transfer in the 1966 decision in Kent v. United States. ${ }^{111}$ In Kent, petitioner Kent was alleged to have committed a number of crimes between the ages of fourteen and sixteen including breaking and entering, robbery, and rape in the District of Colombia. ${ }^{112} \mathrm{He}$ was apprehended for the rape and robbery upon which he admitted his involvement in the current offense. ${ }^{113} \mathrm{He}$ also volunteered information concerning similar offenses. ${ }^{114}$ Kent was sixteen at the time, which placed him within the "exclusive jurisdiction" of the D.C. Juvenile Court. ${ }^{15}$ However, the D.C. statute provided that the district court judge could waive jurisdiction after a "full investigation." ${ }^{116}$ In Kent's

109. MAYS \& RUDDELL, supra note 91.

110. Sellers \& Arrigo, supra note 104.

111. Kent v. United States, 383 U.S. 541 (1966).

112. Id. at 543. Kent was fourteen years old when he was accused of breaking and entering into several homes as well as purse snatching. This precipitated his entry into the juvenile court system. He was placed on probation. Two years later, he was charged with rape, breaking and entering, and robbery. He was sixteen years old.

113. Id. at 544 .

114. Id.

115. Id. at 543 .

116. Id. at 547 . 
case, the district court judge waived juvenile court jurisdiction. ${ }^{117}$ The district court did not hold a hearing, nor did the judge rule on petitioner's motion on the issue of waiver. ${ }^{118}$ On appeal to the United States Supreme Court, Kent attacked the waiver on Due Process grounds. He claimed that that the waiver was defective because no hearing was held and the Juvenile Court judge made no explicit statements for the determination. ${ }^{119}$ The United States Supreme Court agreed. ${ }^{120}$

In an opinion written by Justice Fortas, the Court concluded that the D.C. Juvenile Court Act did not permit a juvenile court judge to decide on its own accord, without any participation from the child or the child's representative, the "critically important" issue of waiver. ${ }^{121}$ For the Court, "there is no place in our system of law for reaching a result of such tremendous consequences without ceremony-without hearing, without effective assistance of counsel, without a statement of reasons." ${ }^{122}$ In discussing the primary function of the Juvenile Court, the Court asserted that Juvenile Court is parens patriae as opposed to a prosecutor or judge. ${ }^{123}$ Juvenile courts are to decide the needs of a child as opposed to criminally prosecute. ${ }^{124}$ Because of this theoretical function, courts have determined that juvenile court proceedings are "civil" as opposed to "criminal" in nature and have prohibited later complaints from juveniles regarding a deprivation of rights. ${ }^{125}$ However, it was well established that a juvenile can claim a deprivation of due process. ${ }^{126}$ With this, the Supreme Court did two important things. First, it established that the decision to transfer a juvenile is a "critically important" proceeding. ${ }^{127}$ For the Court, "an opportunity for a hearing which may be informal, must be given the child prior to entry of a

\footnotetext{
117. Id. at 546 .

118. Id.

119. Id. at 552 .

120. Id.

121. Id. at 553 .

122. Id. at 554 .

123. Id. at 554-55.

124. Id. at 554 .

125. Id. at 555 .

126. Id.

127. Id. at 560 .
} 
waiver order." 128 The Court also required the Juvenile Court to accompany its waiver order with a statement of reasons or considerations. ${ }^{129}$ Such a statement may not be an assumption or boilerplate mimicking the statutory language. At the very least, the statement should include relevant facts so as to provide a factual basis for the waiver determination. ${ }^{130}$ The Kent decision set a minimum standard of due process in juvenile court waiver proceedings. At the very least, a juvenile is entitled to a hearing and representation of counsel. ${ }^{131} \mathrm{To}$ day, Kent is being circumvented by automatic transfer statutes and direct files methods. While Kent requires protections in the context of judicial waiver, it does not speak to legislative directives or prosecutorial discretion. States appear to understand Kent as a judicial waiver case only. However, Kent may be understood as applicable to juvenile transfer generally. Nevertheless, that argument is not an issue currently before the Court.

b. Lower Courts. Wyoming vests jurisdiction over minors charged with violent felonies in both district and juvenile courts. ${ }^{132}$ In evaluating transfer cases, courts are required to consider evidence pertaining to statutory factors. ${ }^{133}$ These factors include the seriousness of the alleged offense and the protection of the community, whether the alleged offense was committed with premeditation and violence, whether the alleged offense was against persons, previous history of the juvenile, and the maturity of the juvenile. ${ }^{134}$ Maturity is to be "determined by consideration of his home, environmental situation, emotional attitude, and pattern of living." 135 Wyoming places the burden of production on the minor requiring him to prove by the preponderance of the evidence that the case ought to be transferred to the juvenile court. ${ }^{136}$ The State, however, maintains the burden of persuading

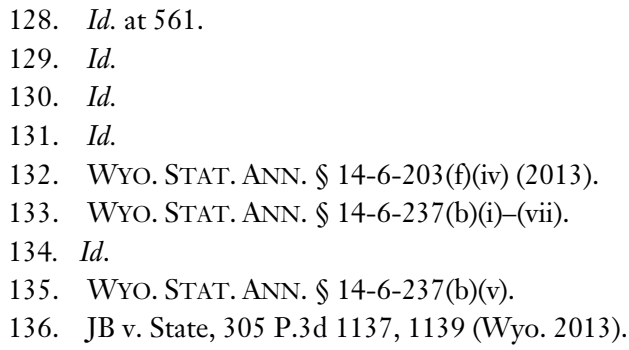


the court that adult court ought to maintain jurisdiction over the minor. ${ }^{137}$

The federal statute governing juvenile transfer is established in the Juvenile Justice and Delinquency Prevention Act. ${ }^{138}$ While the federal system has not established specifically-enumerated juvenile offenses, juveniles may be charged with criminal offenses and prosecuted in adult court. The Act established a number of procedures and required proceedings governing juvenile transfer in the federal jurisdictions. These proceedings have been characterized as "civil" in nature with the government bearing the burden of proving by a preponderance of the evidence the need for transfer. ${ }^{139}$ In order to make its determination, the federal courts must consider evidence pertinent to factors outlined in $\$ 5032 .{ }^{140}$ These factors include:

[T] he age and social background of the juvenile; the nature of the alleged offense; the extent and nature of the juvenile's prior delinquency record; the extent and nature of the of the juvenile's present intellectual development and psychological maturity; the nature of past treatment efforts and the juvenile's response to such efforts; the availability of programs designed to treat the juvenile's behavioral problems. $^{141}$

The court is not required to examine the accuracy of the allegations against the juvenile and may assume that a juvenile has in fact committed the offense. ${ }^{142}$ The court may order transfer if it finds that it "would be in the interest of justice by a preponderance of the evidence." 143

While judicial waiver was the common mode of transfer, today it is the least utilized. With statutory exclusion and direct file methods, the number of juveniles adjudicated in adult court increased seventy-

137. Id. at 1141 .

138. 18 U.S.C. $\$ 5032$ (2012).

139. United States v. A.R., 38 F.3d 699, 703 (3d Cir. 1994); United States v. Juvenile Male \#1, 86 F.3d 1314, 1322-23 (4th Cir. 1996); United States v. T.F.F., 55 F.3d 1118, 1122 (6th Cir. 1995); United States v. Parker, 956 F.2d 169, 171 (8th Cir. 1992).

140. 18 U.S.C. $\$ 5032$ (2012).

141. Id.

142. United States v. Juvenile, 451 F.3d 571, 576 (9th Cir. 2006).

143. United States v. Robinson, 404 F.3d 850, 858 (4th Cir. 2005). 
three percent from 1986 to $1994 .{ }^{144}$ This path leads to a number of problems including high rates of criminal recidivism and disproportionate impact on minority communities and children with disabilities.

\section{Problems with transfer}

A number of issues have surfaced as a result of the frequency of transfer. First, the majority of juveniles transferred to adult court are first time and nonviolent offenders. ${ }^{145}$ Violent juvenile offenders including those convicted of murder and rape comprise less than 0.5 percent of the juvenile offending population. ${ }^{146}$ This category of juvenile offenders was the originally intended target of transfer mechanisms as opposed to nonviolent juveniles. ${ }^{147}$ Legislatures anticipated transfer provisions to apply to serious violent offenders and recidivists. ${ }^{148} \mathrm{How}-$ ever, many of the cases transferred from juvenile court to adult criminal court consist of property and drug crimes. ${ }^{149}$ Transferring non-violent youth will continue to clog an already overburdened adult criminal court docket.

The Juvenile Justice Standards Project of the Institute of Judicial Administration in collaboration with the American Bar Association ("IJA-ABA") produced a set of model rules and standards governing juvenile justice administration. ${ }^{150}$ On the issue of transfer, the IJA-ABA rules encourage a determination by the juvenile court that a juvenile is "not a proper person to be handled by the juvenile court." 151 The standards set out a number of factors meant to guide the court in its evaluation. The factors include the seriousness of the alleged offense,

144. Dana Royce Baerger et al., Competency to Stand Trial in Preadjucated and Petitioned $7 u$ venile Defendants, 31 J. AM. ACAD. PsYCHIATRY \& L. 314, 314 (2003).

145. See Dean J. Champion \& G. Larry Mays, Transferring Juveniles to CRIMINAL COURTS: TRENDS AND IMPLICATIONS FOR CRIMINAL JUSTICE 77 (1991).

146. MichaEl A. Jones \& BARRY KRISBERG, IMAGES AND REALITY: JUVENILE CRIME, Youth Violence AND Public Policy 10 (1994).

147. CHAMPION \& MAYs, supra note 145 , at 79 .

148. Id. at 74 .

149. See Eric Fritsch \& Craig Hemmens, Fuvenile Waiver in the United States 1979-1995: A Comparison and Analysis of State Waiver Statutes, 46 JUV. \& FAM. CT. J. 17, 18 (1995).

150. IJA-ABA Juvenile Justice Standards ANnOtated: A Balanced ApproaCH (Robert E. Shepherd, Jr. ed., 1996).

151. Charles Whitebread, Standards Relating to Transfer Between Courts, in IJA-ABA JUVENILE JUSTICE STANDARDS ANNOTATED: A BALANCED APPROACH supra note 150, at 288. 
criminal history involving violence; the inefficacy of available dispositions; and dispositional alternatives available in the criminal justice system. ${ }^{152}$ The court's determination must be supported by clear and convincing evidence on all of these factors. ${ }^{153}$ The standards encourage that juveniles be given the opportunity to contest waiver by producing evidence that challenges the state's evidence on the matter. ${ }^{154}$

In addition to the frequency of transfer, adult court does not typically have the resources to "treat" juvenile offenders. ${ }^{155}$ Aimed at punishment, adult court does not provide juvenile offenders with treatment and services that contemplate adolescent development and amenability to rehabilitation.

Transferring juveniles to adult court also significantly impacts the life of the individual juvenile. A felony conviction substantially impairs life prospects for all offenders. The stigma that attaches to "felon" status affects both civil liberties and the economic earning capacity of the juvenile. ${ }^{156}$ The cost to the American taxpayer is unquantifiable and is primarily felt on two fronts. First, national and state economies suffer with oppressive expenditures on corrections. In 2007, the federal government spent $\$ 228$ billion dollars on justice administration. ${ }^{157}$ While juvenile justice administration may comprise a smaller percentage of total spending, it substantially contributes to adult corrections expenditures with approximately thirty-five to fifty percent of adult offenders having juvenile histories. ${ }^{158}$ These numbers suggest that the current juvenile system is not functioning so as to divert the juvenile offender away from adult criminality. Instead, it is feeding it.

Shouldering this financial burden is the American taxpayer, who is also losing in the form of squandered social capital and untapped talent. Youth sentenced to detention and imprisonment have less socio-

152. $I d$.

153. $I d$.

154. Id. at 290.

155. CHAMPION \& MAYS, supra note 145 , at $74-75$.

156. Lahny R. Silva, Clean Slate: Expanding Expungements and Pardons for Non-violent Federal Offenders, 79 CINN. L. REV. 155, 165-66 (2011).

157. Tracey Kyckelhahn, Justice Expenditures and Employment 1982-2007 Statistical Tables, NCJ 236218, U.S. DeP’t OF Just., Office of Justice Programs, BUREAU OF JUSTICE STATISTICS (Dec. 2011).

158. Id. 
economic prospects over a lifetime. In general, newly released offenders face high levels of unemployment as well as below-average wages. ${ }^{159}$ On average, incarceration reduces wages by at least eleven percent, cuts yearly employment by nine weeks, and reduces annual earnings by at least forty percent. ${ }^{160}$ When years of work experience are statistically controlled, the results change very little. ${ }^{161}$

The predominance of transfer today speaks to the success (or failure) of the juvenile justice system. In a system where a juvenile may not be a party to a contract, lawfully work and travel, vote, buy alcohol or cigarettes, or even attend an adult motion picture, it seems rather counterintuitive that the same system would permit minors to be prosecuted in adult court. ${ }^{162}$ Scholars continually question whether juvenile justice administration may be considered successful in light of the fact that many juveniles, particularly non-violent, are transferred to adult court to face retributive sanctions. The current system is in effect funneling youth into jail and ultimately results in "felon" status.

\section{B. Incarceration}

Approximately 250,000 juveniles are prosecuted and incarcerated as adults annually. ${ }^{163}$ While juvenile detention itself is fraught with physical and sexual violence, those juveniles transferred and adjudicated in adult court face more severe challenges. Juveniles incarcerated in adult facilities are more likely to be sexually abused and face physical violence. This in turn has damaging effects on the individual's psychosocial development.

Juvenile offenders transferred to adult court are traditionally sentenced to one of three types of imprisonment: segregated incarceration, graduated incarceration, or adult incarceration. ${ }^{164}$ Segregated incarceration separates juvenile and younger offenders from adult

159. Bruce Western \& Becky Petit, Collateral Costs: InCARCERATION'S EFFeCT ON ECONOMic Mobility 11 (The Pew Charitable Trusts, 2010).

160. Id.

161. Id.

162. J.D.B. v. North Carolina, 131 S.Ct. 2394, 2403-04 (2011).

163. Elizabeth Cate, Teach Your Children Well: Proposed Challenges to the Inadequacies of Correctional Special Education for Fuvenile Inmates, 34 N.Y.U REV. L. \& Soc. CHANGE 1, 5 (2010).

164. Bree Langemo, Serious Consequences for Serious Fuvenile Offenders: Do Fuveniles Belong in Adult Court?, 30 OHIO N.U. L. REV. 141, 154 (2004). 
offenders. This separation is maintained until the expiration of the youthful offender's sentence even if the juvenile reaches the age of maturity. ${ }^{165}$ In the graduated incarceration system, the juvenile is detained in a juvenile facility until the individual reaches the age of majority where he or she is subsequently placed in an adult facility. ${ }^{166}$ In the adult incarceration system, a juvenile that is sentenced as an adult is sent to adult prison. ${ }^{167}$

Youth sentenced to adult prison during a developmental era in the adolescents' life when they are pursing social identity, independence, and societal associations will face damaging consequences to the overall health of the individual. ${ }^{168}$ Normal adolescent development occurs within small social networks such a family, school peers, and neighborhoods. ${ }^{169}$

Thus, juvenile offenders sentenced to adult prison will be socialized in prison. Professor Fagan argues that in these circumstances two consequences are likely to occur: "attenuated development of normative developmental skills and states, or skewed development of skills and states that reflect the contingencies and norms of the adult correctional context." ${ }^{170}$ Either way, adolescent development will be distorted by the violent socialization experienced in adult prison facilities. ${ }^{171}$

Juvenile offenders placed in adult institutions face a higher risk of violence than those that are placed in juvenile facilities. "Juveniles in adult institutions are five times more likely to be sexually assaulted, twice as likely to be beaten by staff, and fifty percent more likely to be attacked with a weapon than minors in juvenile facilities." ${ }^{172}$ In addi-

165. Id. See also Nev. DeP’T OF Corr., Administrative Regulation 502 (Oct. 14, 2013).

166. Id.

167. Id. See also Barry C. Feld, Juvenile JustiCe AdMinistration 179, 222 (Thomson West, 2003).

168. Laurence Steinberg \& Elizabeth Cauffman, Maturity of Judgment in Adolescence: Psychosocial Factors in Adolescent Decision Making, 20 L. \& HuM. BEHAV. 249, 268 (1996).

169. Jeffrey Fagan, This Will Hurt Me More Than It Hurts You: Social and Legal Consequences of Criminalizing Delinquency, 16 NOTRE DAME J.L. ETHICS \& PUB. POL'Y 1, 32 (2002).

170. Id. at 34 .

171. Id. at 35 .

172. Lisa S. Beresford, Is Lowering the Age at Which fuveniles Can Be Transferred to Adult 
tion, adult correctional facilities are inadequately equipped with treatment and programming appropriate for servicing youth. ${ }^{173}$ Poor vocational and educational training serve to weaken opportunities of socioeconomic mobility while prison culture tends to encourage violence as a problem-solving and status-building technique. ${ }^{174}$ Juveniles will therefore re-enter society with rather large developmental deficits as well as weakened social ties to the offender's community. ${ }^{175}$

\section{Recidivism}

A number of studies have determined that transfer to adult court actually increases the rate of recidivism for juvenile offenders. ${ }^{176}$ Moreover, those juveniles sentenced to adult prison also have higher rates of recidivism. ${ }^{177}$ Those punished as adults are three times more likely to recidivate than those retained in the juvenile system. ${ }^{178}$

A research study conducted in Minneapolis, Minnesota from 1986-1992 reported that fifty-eight percent of youths transferred to adult court committed a new offense(s) within two years of conviction while forty-two percent of youths retained in juvenile court recidivated. ${ }^{179}$

A Florida study showed similar results with the recidivism rates within three years of conviction at thirty percent for transferred youth compared to nineteen percent in juvenile court. ${ }^{180}$

A study that compared the recidivism rate for juvenile robbery offenders reported that those transferred to adult court consistently had

Criminal Court the Answer to fuvenile Crime? A State-by-State Assessment, 37 SAN DIEGo L. REV. 783, 821-22 (2000); see also Jarod K. Hofacket, fustice or Vengeance: How Young Is Too Young for a Child to Be Tried and Punished as an Adult?, 34 Tex. TECH. L. REV. 159, 173 (2003).

173. Fagan, supra note 169 , at 33 .

174. Id.

175. Id.

176. For discussions of these studies, see Angell, supra note 69, at 140 ; Fagan, supra note 169, at 24-28; Donna M. Bishop, Fuvenile Offenders in the Adult Criminal System, in CRIME AND JustiCE: A REVIEW OF RESEARCH 81-167 (Michael Tonry ed., 2000); Beresford, supra note 172, at 822 .

177. Donna M. Bishop \& Charles E. Frazier, Race Effects in fuvenile fustice Decision-Making: Findings of a Statewide Analysis, 86 J. CRIM. L. \& CRIMINOLOGY 392 (2000).

178. Id.

179. Fagan, supra note 169 , at 24.

180. Id. at 25 . 
a higher recidivism rate than those kept in juvenile court. ${ }^{181}$ The study also reported that the re-arrest rate for juveniles incarcerated in adult prison was twenty-five percent higher than those detained in a juvenile facility. ${ }^{182}$

A Florida study, using data from between 1985 and 1987, compared youth who were transferred to adult court to those youth processed in juvenile court. ${ }^{183}$ In this study, researchers paired offenders based on specific characteristics including age, race, gender, type of offense, criminal history, etc. ${ }^{184}$ The study conducted two separate assessments. ${ }^{185}$ The study reported that transfer to adult court increased recidivism in all seven offenses used in the study. ${ }^{186}$

\section{Disproportionate Impact}

\section{Minority children}

From the early nineteenth century to the present, juvenile justice has systematically singled out poor children for punishment while their middle and upper class counterparts were given more lenient treatment. The current overrepresentation of poor black children in the juvenile justice system is an extension of this tradition. A comprehensive analysis regarding racial disproportionality requires an examination of law enforcement and juvenile justice system policies and practices that is beyond the scope of this article. For purposes of the present research issues, statistics will inform the analysis.

Black juvenile offenders are more likely to be waived and processed in criminal court. ${ }^{187}$ Black youth comprise thirty-seven percent of

181. Id. at 27 .

182. Id.

183. Donna M. Bishop et al., The Transfer of Juveniles to Criminal Court: Does it Make a Difference?, 42 CRIME \& DELINQ. 171, 175 (1996).

184. Id. at 176-77.

185. Id.

186. Id. at 183 .

187. Kristi Holsinger, Youth in the Fuvenile fustice System: Characteristics and Patterns of Involvement, in Juvenile Justice: Advancing Research, Policy, and Practice 24, 37 (Francine T. Sherman \& Francine H. Jacobs eds., 2011). 
transfer decisions while fifty-nine percent of white youth are transferred to criminal court. ${ }^{188}$ Latino youth are also disproportionately represented in transfer decisions. However, accurate data on this demographic is difficult to ascertain due to "shortcomings in available data." 189

In 2003 , there were more than 59,000 minority offenders in juvenile facilities across the country comprising sixty-one percent of those in detention. ${ }^{190}$ Black youths specifically accounted for thirty-eight percent of all offenders. Currently, black juveniles have the highest proportionate rate of detention among racial groups. The Justice Department reports that for every 100,000 black juveniles living in the U.S., 754 were detained in a juvenile facility in 2003 as compared to the detention rate of 348 for Hispanics and 190 for whites. ${ }^{191}$ In every state except Vermont, the custody rate for black juvenile offenders exceeds the rate for whites. ${ }^{192}$ Nationally, the ratio of the custody rate for minorities to that of whites was 2.6 to $1 .{ }^{193}$ This trend can also been seen across the states. For example, minority youth between the ages of ten and seventeen represent less than twenty-five percent of the Florida population but comprise fifty-five percent of the juvenile transfers to adult court. ${ }^{194}$

The disproportionate impact of transfer on minority offenders follows that group throughout the processes associated with the administration of justice. Minority juveniles were more likely than white juveniles to be in facilities with locked doors or gates. ${ }^{195}$ Among minorities, Hispanic youth were more likely to be held under locked arrangements than were other minorities. ${ }^{196}$ "Minority offenders in California are more likely than white offenders to receive harsher sentences for equivalent offenses." ${ }^{197}$

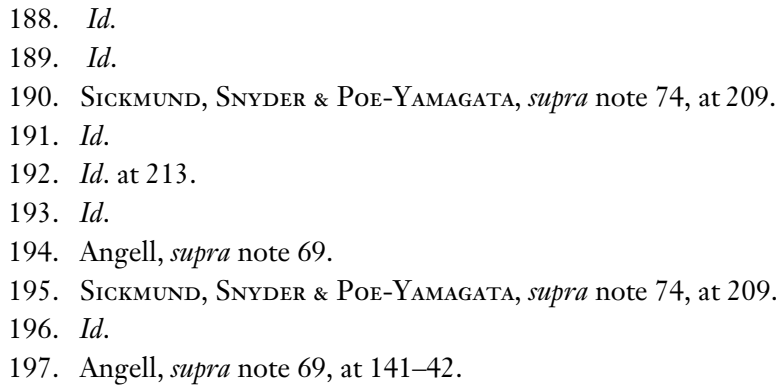


Furthermore, the disproportionate number of minority juvenile offenders processed through the juvenile justice system means an unbalanced number of minority men living with the collateral consequences associated with "felon" status. This translates into lifetime opportunity loss for the offender in the areas of employment, education, civil liberties, and government benefits.

\section{Children with disabilities}

Minorities are not the only demographic with disproportionate representation. Children with special education needs are also disproportionately represented. One judge in Nevada commented,

More and more minors are getting involved in the juvenile justice system because they have mental-health needs that are not being treated. They are acting out; they are committing offenses because they have mental-health problems that need to be addressed. Although we certainly get some violent crimes and drug problems, the main things we are seeing are cases where families are in desperate need of help for kids who have mental-health problems. ${ }^{198}$

Youth with mental disabilities represent nine percent of the juvenile population but generally represent thirty-six percent of juvenile offenders. ${ }^{199}$ Other studies report that eighty-five percent of juveniles currently in correctional facilities need mental health treatment. ${ }^{200}$

While the early implementation of Progressive ideals may not be adequate in addressing today's concerns, there are important and valuable principles that may be taken from the overall theoretical basis of the Progressive movement itself and interposed in the current dialogue concerning juvenile justice administration. The principle that children are amenable to reform as well as the idea that the "Best Interest of the Child" ought to guide determinations in transfer decisions are normative ideals that are worth preserving.

198. Richard D. Williamson, Tracking Trends in Fuvenile fustice, 16 NEv. LaW. 20, 20 (2008) (quoting Judge Schmuck).

199. Cate, supra note 163, at 10.

200. Kristina Menzel, The School-to-Prison Pipeline: How Schools are Failing to Properly Identify and Service Their Education Students and How One Probation Department Has Responded to the Crisis, 15.3 LOY. PUB. INT. L. REP. 198, 200 (2010). 


\section{Mitigations as the Portal}

In the new millennium, scholars and researchers possess over a century of jurisprudence as well as empirical and scientific data that allow for the formulation of a theoretical framework that can help guide legislatures in fashioning an appropriate and workable juvenile justice system. Elizabeth Scott and Laurence Steinberg have developed a theoretical model espousing mitigation-based principles in the assessment of juvenile crime. ${ }^{201}$ Their mitigation model of juvenile justice implicitly recognizes "Best Interest" ideals. Their model, backed by recent psychosocial research and United States Supreme Court precedent, focuses on the differences in criminal culpability and blameworthiness between juveniles and adults. ${ }^{202}$ Because of the psychological and biological evidence affirmatively showing real differences in decision-making capabilities between adolescents and adults, the law should recognize these differences in meting out punishment. The United State Supreme Court has identified and adopted such distinctions in its assessment of the constitutionality of the death penalty and later in the administration of life imprisonment without the possibility of parole in non-homicidal criminal cases for juveniles. The recognition and consideration of the mitigating aspects of youth suggest that this framework is a natural and logical extension of juvenile justice jurisprudence.

\section{A. The Paradigm of Mitigation}

Scott and Steinberg's groundbreaking article, Blaming Youth, ${ }^{203} \mathrm{de}-$ velops a, theoretical framework for thinking about justice policy and "the empirical reality of adolescence." 204 They have developed a mitigation based model of juvenile justice premised on proportionality and diminished capacity. ${ }^{205}$ Weighing heavily on the adolescent developmental factors discussed below, they argue that these developmental

201. Scott \& Steinberg, supra note 4 , at 838 .

202. $I d$.

203. Id.

204. Id. at 839 .

205. Id. 
influences "undermine decision-making capacity in ways that are accepted as mitigating culpability." 206 The underlying premises of their model include: 1) psychosocial immaturity of juveniles and scientific evidence demonstrating biological distinctions between juveniles and adults and 2) mitigation of criminal culpability in criminal law. ${ }^{207}$ These differences, while significant, do not absolutely excuse an adolescent's criminal conduct. ${ }^{208}$ Instead, they argue, distinctions ought to be treated as mitigation in criminal punishment requiring proportionality in accordance with this diminished blameworthiness reflected in the overall sentence. ${ }^{209}$

This paradigm recognizes an important "Best Interests" ideal: youths are capable of change. With regard to impulsivity and mood control, Scott and Steinberg discuss the notion that adolescents may have more trouble controlling impulses and moods than adults. ${ }^{210}$ In accordance with this proposition, they cite research reporting that impulsivity eventually declines during early adulthood. ${ }^{211}$ Explicit recognition of the fact that most youthful offenders do not develop into adult criminals provides strong support for their overall thesis that because juveniles are immature, they possess a diminished criminal culpability that ought to serve as a basis for mitigation in punishment. In implementing a mitigation based approach to juvenile justice, Scott and Steinberg consider the same psychosocial factors as the United States Supreme Court. The framework comports with the most current understandings of adolescent development and implicitly promotes "Best Interests" considerations. On a structural level, Scott and Steinberg consider application primarily in the context of punishment and explore the potential for its use in other circumstances in the adult prosecution of juveniles. ${ }^{212}$ They consider a more individualized con-

206. Id. at 830 .

207. Id. at 829-32.

208. Id.

209. $I d$.

210. Id. at 816 .

211. Scott \& Steinberg, supra note 4 (citing Laurence Steinberg \& Elizabeth Cauffman, Maturity of Judgment in Adolescence: Psychosocial Factors in Adolescent Decisionmaking, 20 LAW \& HuM. BEHAV. 249, 260 (1996)).

212. Id. at $837-38$. 
sideration of mitigation based on immaturity but dismiss such a presumption as an "error-prone undertaking, with the outcomes determined by factors other than immaturity." 13 While maybe not a workable presumption in the context of punishment, a presumption of immaturity may work before the adult prosecution of a juvenile even begins: transfer.

\section{B. The Sciences}

Recent advances in neuroscience as well psychology have informed scholars, courts, and policymakers in the mental capabilities of juveniles. Mounting physiological and biological research suggests that juveniles are biologically different from adults. Recent neuro-scientific research in the brain development of pre-teens and teenagers demonstrate that there are real and substantial distinctions in the capacities between juveniles and adults that are related to the determination of criminal culpability. Such date has been used as the primary reasoning underlying recent United State Supreme Court decisions treating juveniles different than adults in criminal investigation and prosecution. With these developments in science and law comes the responsibility of lawmakers to examine the data and fashion juvenile justice policy accordingly.

Criminal culpability requires the determination of responsibility for a willful act. Responsibility in turn requires the capacity to be accountable for one's deliberate actions. The ability to generate actions that are willful and planned requires psychological abilities that are supported by the complex brain mechanisms discussed below. These physiological mechanisms are related to "[e]xecutive function and cognitive control are terms used in psychology and neuroscience to describe the ability to generate actions that are voluntary and goal-directed." 14 These functions include self-monitoring and "inhibition of distracting impulses." ${ }^{15}$ Immature executive function and decreased cognitive control substantially inhibit a juvenile's ability to adequately assess circumstances in which responsibility and consequences are

213. Id. at 837 .

214. Beatriz Luna, Relevance of Immaturities in the fuvenile Brain from Culpability and Rehabilitation, 63 HASTINGS L.J. 1469, 1471 (2012).

215. Id. 
given the requisite consideration for purposes of criminal prosecution. $^{216}$

A recent article in the Hastings Law Journal discusses this very phenomenon. ${ }^{217}$ The article asserts that although the basic ability to voluntarily inhibit responses is available at infancy, the ability to generate correct inhibitory responses" is the measure to which adult cognitive control is evaluated. ${ }^{218}$ In the best case scenario, "adult level cognitive control is evident by fifteen years of age." ${ }^{219}$ An MRI scanner has demonstrated that:

[W] $]$ here anxiety increases, performance deteriorates compared to adults, suggesting that while they have access to adult level inhibitory control, it is still immature and susceptible to errors. Given known increased reactivity to socioemotional stimuli, this could undermine the ability to apply inhibitory control. ${ }^{220}$

The frontal lobes are the area of the brain that is associated with the development of critical judgment and learning. ${ }^{221}$ A reduction of blood flow to this area of the brain, a condition known as hypofrontality, is known to be present in post-traumatic stress disorder, bi-polar disorder, and depression. ${ }^{222}$ Normal adolescents show a mild form of hypofrontality. ${ }^{223}$ Testing demonstrates mild decreases in frontal lobe function. ${ }^{224}$ When this is coupled with increased levels of sex hormones associated with puberty the result can be hyperresponsiveness to stimuli. ${ }^{225}$

It has also recently been discovered that the maturation in the part of the brain responsible for making sound judgments and calming disruptive emotions, the systems in the ventromedial and dorsolateral regions of the prefrontal cortex, occur later in adolescent development

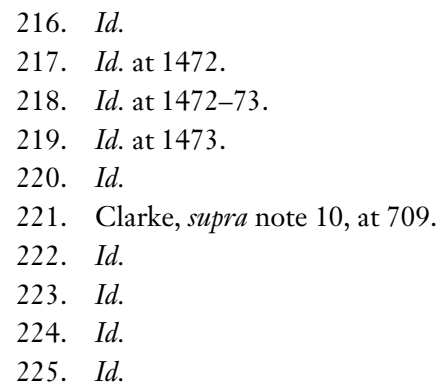


than previously thought. ${ }^{226}$ It is now believed that the ultimate stage of development in this area of the brain actually occurs in an individual's twenties. ${ }^{227}$ These areas of the brain are associated with self-control, inhibiting impulsive action, social judgment, and cost-benefit analyses in decision-making situations. ${ }^{228}$ Research has also demonstrated that completion of the physiological development of the brain; the sheathing of the nerves, which connect different processing centers, is not ultimately finished until the early twenties. ${ }^{229}$ This sheathing also affects the part of the brain that "regulate[s] emotion, judgment, and impulse control." 230

Impulsivity, a hallmark characteristic of adolescent behavior, has been examined quite extensively in recent years. Defined as, "a predisposition toward rapid, unplanned reactions to internal or external stimuli without regard to the negative consequences of these reactions to the impulsive individuals or others" 231 impulsivity is action with "minimal or complete lack of forethought." 232 A recent research study published by Laurence Steinberg reports significant age differences in planning ahead, time perspective and anticipation of future consequences. ${ }^{233} \mathrm{With}$ this, the impulsivity inherent in adolescents is directly related to the moral culpability of a juvenile offender.

The significance of these physiological and brain science advances is quite clear. Adolescents are not comparable to adults in decisionmaking capacities because of the developmental differences. Hyperresponsiveness to stimuli, immaturity in brain development, and the

226. Shannon Brownlee et al., Inside the Teen Brain, U.S. NEWS \& WORLD REPORT, Aug. 9, 1999, at 44; Luna, supra note 214, at 1478.

227. John McCrone, Rebels with a Cause, New SCIENTIST, Jan. 22, 2000, at 2.

228. L.P. Spear, The Adolescent Brain and Age-Related Behavioral Manifestations, 24 NEURosCiENCE \& BioHaVioral REVIEWS 417 (2000).

229. Brownlee, supra note 226, at 5.

230. Id. at 5-6.

231. Matthew S. Stanford et al., Fifty Years of the Barrett Impulsiveness Scale: An Update and Review, 47 Personality \& INDIVIDUAl DifFERENCES 385, 385 (2009) (citing F. G. Moeller, et al., Psychiatric aspects of impulsivity, AM. J. PsYCHIATRY 158, 1783-1793 (2001)).

232. Marsha Levick, Jessica Feierman, Sharon Messenheimer Kellley, Naomi E.S. Goldstein \& Kacey Mordecai, The Eighth Amendment Evolves: Defining Cruel and Unusual Punishment Through The Lens of Childhood And Adolescence, 15 U. PA. J. L. \& Soc. Change 285, 295 (2012).

233. Laurence Steinberg et al., Age Differences in Future Orientation and Delay Discounting, 80 CHILD. DEV. 28, 34-35 (2009). 
lack of a fully developed sheathing process together result in an undeveloped youth who is incapable of engaging in the full range of processes required in adult type decision-making. This in turn affects judgment and criminal blameworthiness.

The physiological and biological immaturities in the adolescent brain do not satisfy traditional notions of criminal culpability inherent in the mens rea requirements of criminal offenses including "willful act" or "deliberate indifference." At most, juvenile offenders would be "reckless" or "negligent." That a juvenile has not reached full maturity and is acting without optimal executive control should be considered not only when making transfer determinations but also in the overall sanctioning of youthful offenders. The United States Supreme Court has taken such information into account in recent decisions.

\section{United States Supreme Court Precedent}

Over the past decade the Supreme Court has cultivated important substantive jurisprudence in the area of adolescent development and the distinctions between adolescents and adults. ${ }^{234}$ The Court has repeatedly asserted that a child's age is "more than a chronological fact." ${ }^{235}$ Over the years, this principle has evolved into a body of law centered on the idea that minors are less mature than adults and are more susceptible to outside influences. ${ }^{236}$

In the 2005 United States Supreme Court case of Roper v. Sim$m o n s,{ }^{237}$ the Court was asked to review the constitutionality of the death penalty as a sentence meted out to juvenile offenders in homicidal cases. Taking center stage was the issue concerning the psychosocial and biological differences between juveniles and adults. Writing for the majority, Justice Kennedy embraced the notion that juveniles (under the age of eighteen) were categorically less blameworthy than

234. J.D.B. v. North Carolina, 131 S.Ct. 2394 (2011); Graham v. Florida, 130 S.Ct. 2011 (2010); Gall v. United States, 552 U.S. 38 (2007); Roper v. Simmons, 543 U.S. 551 (2005); Johnson v. Texas, 509 U.S. 350 (1993); Eddings v. Oklahoma, 445 U.S. 104 (1982); Bellotti v. Baird, 442 U.S. 622 (1979) (plurality opinion).

235. J.D.B. v. North Carolina, 131 S. Ct. 2394, 2403 (2011); Roper v. Simmons, 543 U.S. 551, 569 (2005); Eddings v. Oklahoma, 445 U.S. 104, 115 (1982).

236. J.D.B. v. North Carolina, 131 S. Ct. 2394, 2403 (2011).

237. Roper, 543 U.S. 551 (2005). 
adults and thus could not receive the death penalty. ${ }^{238}$ In its reasoning the Court specifically discussed recognized three important differences between juveniles and adults. First, the Court recognized the recent scientific and psychological studies that to real differences between juveniles and adults. ${ }^{239}$ Kennedy asserted,

[A]s any parent knows and as the scientific and sociological studies respondent and his amici cite tend to confirm, "[a] lack of maturity and an underdeveloped sense of responsibility are found in youth more often than in adults and are more understandable among the young. These qualities often result in impetuous and ill-considered actions and decisions. ${ }^{240}$

Second, the Roper Court also recognized that juveniles were more susceptible to peer pressure. ${ }^{241}$ Citing a recent article by Elizabeth Scott and Laurence Steinberg, the Court concluded that this vulnerability to outside pressures "is explained in part by the prevailing circumstances that juveniles have less control, or less experience with control, over their own environment." ${ }^{242}$ With this, the Court recognizes that minors lack the impulse controls that adults have or ought to have. Finally, the Court asserted "that the character of a juvenile is not as well formed as that of an adult." ${ }^{243}$ For the Court, the factors contributing to this immaturity diminishes the moral culpability of the juvenile's conduct. ${ }^{244}$ Moreover, these very characteristics that make a juvenile reckless and impetuous are transient, and as the youth mature and grow these characteristics may subside and dissipate. ${ }^{245}$ Dissenting, Justice Scalia's argument on these points was that the studies "in no way justify a constitutional imperative that prevents legislatures and juries from treating exceptional cases in an exceptional way." ${ }^{46}$ With most of the members of the Court finding merit in the psychological and brain science studies provided by the respondent and his amici, the

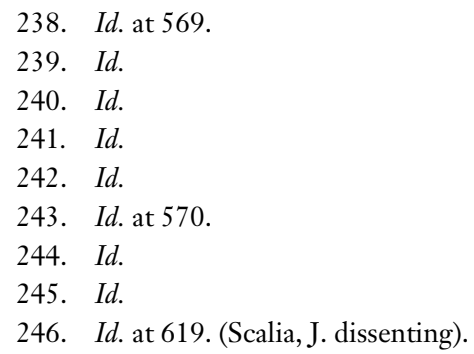


Court began the transformation of the treatment of juvenile offenders in the American criminal justice system.

In 2010, Graham v. Florida ${ }^{247}$ was decided. The issue before the Court was whether a juvenile could be constitutionally sentenced to life imprisonment without the possibility of parole for a non-homicide offense. ${ }^{248}$ Justice Kennedy, again writing for the majority, cited the scientific and psychological research in Roper as well as emerging developments in the field of neuroscience to invalidate the sentence on Eighth Amendment grounds. ${ }^{249}$ Moreover, the Court cited a number of amici that pointed out the biological and psychological developmental differences of juveniles as data supporting its holding. ${ }^{250}$ Finding merit in the argument that juveniles are more capable of reformation and change than adults, the Court decided that courts ought to treat juveniles differently than adults in jurisdictions that mete out sentences of life imprisonment without the possibility of parole in non-homicidal offenses. ${ }^{251}$ Specifically, Justice Kennedy concluded that juveniles (like the appellant) possess a "twice diminished moral culpability." 252

The Court also cited the research relied on in Roper and Graham in its 2011 decision in $7 D B$. v. North Carolina. ${ }^{253}$ In that case, the Supreme Court held that a child's age was relevant to the "custody" determination as well as the decision to administer Miranda warnings. ${ }^{254}$ Writing for the majority, Justice Sotomayor asserted that "children characteristically lack the capacity to exercise mature judgment and possess only an incomplete ability to understand the world around them." ${ }^{255}$ More specifically in the context of police questioning and interrogation, Justice Sotomayor quoted precedent stating, "events that "would leave a man cold and unimpressed can overawe and overwhelm a lad in his early teens.'"256

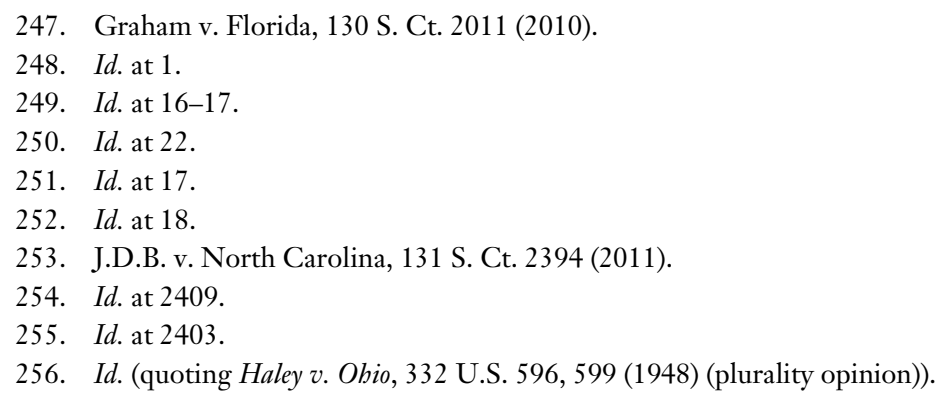


With this, the Court further entrenched the notion that juveniles are different than adults and should be treated as such. This time, the Court extended the principle outside the context of punishment and applied it to the prophylactic constitutional protections of Miranda.

The most recent Supreme Court decision recognizing a distinction between juveniles and adults occurred in the 2012 case of Miller v. Alabama. ${ }^{257}$ In Miller, the juvenile petitioners were charged and convicted of murder and sentenced in accordance to state statute to life imprisonment without the possibility of parole. ${ }^{258}$ The Court held that life imprisonment without the possibility of parole for those who committed crimes when they were under the age of eighteen constituted cruel and unusual punishment, thereby violating the Eighth Amendment. ${ }^{259}$ Relying heavily on the principles and studies discussed in Roper and Grabam, the Miller Court insisted that a sentencing court have the ability to consider information regarding characteristics inherent in adolescent development and the lesser culpability of youths generally. ${ }^{260}$

In the past ten years, the United States Supreme Court has effectively re-shaped our thinking about the treatment of juveniles in our system of criminal justice. For the Court, the physiological, psychological, and biological differences matter. Moreover, this immaturity and inability to adequately render decisions convinces the Court that juveniles are incapable of forming the mens rea required to be punished as adults in the most severe criminal cases. With jurisprudence in this area evolving towards treating juveniles differently, state courts are forced to take notice and move forward accordingly.

257. Miller v. Alabama, 132 S. Ct. 2455 (U.S. 2012).

258. Id. at 2460-63. There were two petitioners in this case. Petitioner Kuntrell Jackson was fourteen years old when he was charged with capital felony murder and aggravated robbery in Arkansas. The prosecutor directly filed into adult court. Petitioner Jackson moved to transfer the case to juvenile court but the trial court denied the motion and the appellate court affirmed. Petitioner Miller, fourteen at the time of the alleged crimes, was charged and convicted of murder in the course of arson. The prosecutor moved to transfer the case to district court. Miller appealed. In affirming the district court, the Alabama Court of Appeals cited Miller's "mental maturity" and his criminal history.

259. Id. at 2469 .

260. Id. at 2467. 


\section{Summary}

Scott and Steinberg's mitigation paradigm serves as a portal for legislators to remain faithful to Best Interest ideals. Focusing on a lesser culpability, immaturity, and the likelihood for change, Scott and Steinberg's diminished culpability framework provides a platform for the development of other legal tools to protect youth from their own flawed decision-making. Backed by the sciences and encouraged by stare decisis, a mitigation approach to juvenile justice may provide a basis for the establishment of a legislative safety valve prior to the transfer decision and the creation of a partial defense in adult criminal prosecutions.

\section{Best Interest of the Child Modified}

Taking into account the contemporary understanding of adolescent development, it is important to ensure that the law and policy governing juvenile crime reflect this knowledge. One resolution is to allow evidence of a juvenile's neuro-psychological development to enter into transfer determinations of prosecutors, judges, and legislative mandate. By allowing the decision-maker to consider the immaturity and mental capacity of the individual offender, courts will be required to take a closer look at not only the individual offender but also at the information and data on adolescent development. Another method that will ensure the presentation of such evidence is to permit juvenile offenders prosecuted in adult court to present a partial defense of diminished capacity thereby allowing for the possible mitigation of the offense in general. This section explores both of these options in detail.

\section{A. Presumption of Immaturity}

In order to ensure that juvenile justice administration is keeping with the foundational ideals of the Best Interest, it is critical to fashion a procedure that recognizes both the psychosocial concerns in adolescent development as well as recent United States Supreme Court precedent. The Court has stated that "the State is entitled to adjust its legal 
system to account for children's vulnerability." 261 A minor's susceptibility to outside pressures and peer influence, impulsivity, and a general lack of perspective and judgment places a moral imperative on the State to consider these factors in evaluating a transfer decision. For the Court, "The State has a strong and legitimate interest in the welfare of its young citizens, who immaturity, inexperience, and lack of judgment may sometimes impair their ability to exercise their rights wisely." ${ }^{262}$ Thus, the state must consider it a duty to protect juveniles from themselves.

One way that states may protect its minors is to presume immaturity and work toward a solution or disposition from that point. Recognized in the context of minor abortions, the presumption of immaturity posits that juveniles are not mature enough to decide whether to undergo an abortion and therefore parental involvement is legally required in the decision-making process. ${ }^{263}$ This principle is easily transferrable in the context of juvenile justice administration, particularly in the context of juvenile transfers to adult court. The idea is that prior to an adult criminal prosecution, a juvenile within a specific age range (fourteen to seventeen years old) would be presumed immature. This presumption of immaturity seeks to protect juveniles from an imbalanced administration of justice. The presumption asserts that because the juvenile is a certain age, he has not fully developed psychosocially and is thereby less blameworthy than an adult. The State, wanting to rebut the presumption, must produce evidence showing that the juvenile is mature and as blameworthy as an adult. The following section discusses presumptions generally, the presumption of immaturity used in the abortion context, and the application of this presumption in the context of juvenile justice administration.

\section{Presumption of immaturity}

A presumption concerns a legally acknowledged relationship between facts. ${ }^{264} \mathrm{It}$ is a rule of law and requires that once specific facts are established ("basic facts"), the existence of another fact ("presumed

261. Bellotti v. Baird, 443 U.S. 622, 635 (1979) (quoting plurality opinion).

262. Hodgson v. Minnesota, 497 U.S. 417, 444 (1990).

263. Bellotti v. Baird, 443 U.S. 622 (1979).

264. Joshua DresSLER, UNDERSTANDING CRIMINAL LAW 63 (2d ed. 1995). 
fact") must be taken as established unless a certain condition is fulfilled. ${ }^{265}$ In an attempt to decipher the operationalization of presumptions with the introduction of rebuttal evidence, two separate approaches have evolved: Thayer's "bursting bubble" approach and the Morgan approach. Under the "bursting bubble" approach a presumption will dissipate when the presumed fact is contradicted by credible evidence. ${ }^{266}$ With this, the opponent of the presumption is required to introduce evidence sufficient to support a contrary finding to the presumption. The opponent only carries the burden of production. The Morgan theory requires the judge to instruct the jury that it must find fact $B$ if they find fact $A$, unless the opponent of the presumption persuades the jury that the absence of fact $B$ is more probably true than not. ${ }^{267}$ This approach, in effect, places both the burden of production and the burden of persuasion on the opponent.

There are two different types of presumptions in the criminal context: mandatory presumptions and permissive presumptions. Mandatory presumptions are either rebuttable or irrebuttable presumptions. A mandatory rebuttable presumption requires a finding of the presumed fact upon proof of the basic fact unless the opposing party rebuts the presumption. The procedural effect of this type of presumption is to shift the burden of persuasion to the opponent regarding the presumed fact once the basic fact is established. This burden shifting is constitutionally permissible so long as the presumed fact is not an element of a charged offense. ${ }^{268}$ An irrebuttable mandatory presumption requires that the factfinder find the presumed fact upon proof of the basic fact although the opposing party rebuts the presumed fact. Irrebuttable mandatory presumptions are rare in criminal law. Permissive presumptions allow the factfinder to find the presumed fact but does not require the finding. This is not a burden shifting exercise. Instead, the permissive presumption provides a connection between the basic fact and the fact at issue thereby giving the factfinder discretion in presuming a fact. ${ }^{269}$

265. Edmund Morgan, Basic Problems of Evidence 37 (1961).

266. Id. at 34-35.

267. Morgan, Instructing the fury Upon Presumptions and Burden of Proof, 47 HaRV. L. REV. 59, 82-83 (1933).

268. Sandstrom v. Montana, 442 U.S. 510 (1979).

269. County Court of Ulster County v. Allen, 442 U.S. 140, 157 (1979). 
The United States Supreme Court has stated that the due process clauses of the Fifth and Fourteenth Amendments serve as a limit on a legislature's ability to create presumptions. ${ }^{270}$ In order to pass constitutional muster, there must be a "rational connection" between the facts proven and the fact presumed "and the latter is "more likely than not to flow from' the former."271

Under our decisions, a statutory presumption cannot be sustained if there be no rational connection between the fact proved and the ultimate fact presumed, if the inference of the one from proof of the other is arbitrary because of a lack of a connection between the two in common experience. This is not to say that a valid presumption may not be created upon a view of relation broader than that a jury might take in a specific case. But where the inference is so strained as not to have a reasonable relation to the circumstances of life as we know them, it is not competent for the legislature to create it as a rule governing the procedure of courts. ${ }^{272}$

The standard for reviewing presumptions sets a relatively low bar. So long as there is a reasonable relation between the basic fact and the presumed fact, a presumption ought to pass constitutional scrutiny. However, mandatory presumptions are typically disfavored as courts perceive them to weaken the strength of the threshold burden of proof as well as complicate the assignment of the burden. ${ }^{273}$

\section{Presumption of immaturity in the courts}

a. United State Supreme Court and Bellotti. The United States Supreme Court has dealt with presumptions in a variety of settings and has in fact reviewed the presumption of immaturity, albeit implicitly. In Bellotti v. Baird, ${ }^{274}$ the Court invalidated a Massachusetts statute requiring parental consent or parental notification before a minor was permitted to have an abortion. The Court determined that in order for such regulations to pass constitutional muster, statutes must implement procedures permitting minors to bypass parental consent

270. Tot v. United States, 319 U.S. 463, 467 (1943).

271. County Court of Ulster County v. Allen, 442 U.S. 140, 165 (1979).

272. Tot, 319 U.S. at 467-68.

273. Id.

274. Bellotti v. Baird, 443 U.S. 622 (1979). 
and notification. ${ }^{275}$ This mechanism is known as a "judicial bypass provision." 276 Judicial bypass is a procedural mechanism that rests on a showing of maturity or a Best Interest evaluation. In the case of "maturity," judicial bypass allows minors to petition the court to rebut the presumption of immaturity by showing that they have the capability to make an informed abortion decision. Judicial bypass also serves as protection for incompetent minors from immature decisionmaking. ${ }^{277} \mathrm{~A}$ finding of sufficient maturity permits the judge to waive parental involvement. A finding of immaturity may still permit the judge to waive parental involvement so long as the judge believes it would be in the minor's best interest.

In discussing its concern for the vulnerability of minors, the Bellotti Court asserted that "during the formative years of childhood and adolescence, minors often lack the experience, perspective, and judgment to recognize and avoid choices that could be detrimental to them."278 For the plurality, Justice Powell cited First Amendment jurisprudence for support including Ginsberg v. New York ${ }^{279}$ and Prince v. Massacbusetts, ${ }^{280}$ both cases where the Court, concerned with the immaturity of a minor's decision making, upheld state restrictions on a minor's freedom. For the Court "immature minors often lack the ability to make fully informed choices that take account of both the immediate and long range consequences." 281 Justice Powell also discussed three reasons why the constitutional rights of children are not the equivalent of those of adults: ". . . the peculiar vulnerability of children; their inability to make critical decisions in an informed, mature manner; and the importance of the parental role in child rearing." ${ }^{282}$ This is manifested in the a number of different contexts such as voting, service in the military, purchasing alcohol and tobacco, entering contracts, etc.

275. Id. at $643-44$.

276. Id. at 651 .

277. Satsie Veith, The Fudicial Bypass Procedure and Adolescents' Abortion Rights: The Fallacy of the Maturity Standard, 23 HOFSTRA L. REV. 453 (1994).

278. Bellotti, 443 U.S. at 635.

279. Ginsberg v. New York, 390 U.S. 629 (1968). The Court upheld a New York statute that restricted the sale to children under the age of seventeen of sexually oriented magazines.

280. Prince v. Massachusetts, 321 U.S. 158 (1944). The Court upheld a Massachusetts child-labor statute that prohibited children from selling religious literature on a public street.

281. Bellotti, 443 U.S at 640.

282. Id. at 634 . 
The United States Supreme Court has not overtly defined "maturity." The Court has discussed the term and the concept in a number of different contexts, but has yet to define the term or announce factors to be considered in making a "maturity" assessment. It came closest to announcing a principle in Bellotti, when Justice Powell remarked that "immature minors often lack the ability to make fully informed choices that account of both immediate and long range consequences. . .."283 For the plurality, immaturity denotes an inability to evaluate choices in both the short and long term. Moreover, immature minors are incapable of making informed decisions. Most important, the Court implicitly recognizes that immaturity is an intrinsic characteristic of minors. Lower courts have used this principle to shape factors that could be considered in making a maturity assessment.

b. Lower Courts. Lower courts have used the dicta in Bellotti to fashion standards and rules governing maturity determinations. In H.B. v. Wilkinson, ${ }^{284}$ District Court Judge Thomas Greene utilized the principle announced in Bellotti to construct a framework to which "maturity" may be analyzed by courts. The district court dismissed a pregnant minor's lawsuit seeking to prevent a physician from notifying her parents of the minor's decision to seek an abortion. ${ }^{285}$ In essence, she challenged the Utah Statute requiring notification to an immature minor's parents of the minor's consideration of abortion. ${ }^{286}$ In order to assess the minor's "maturity," the district court reviewed the importance of "experience, perspective, and judgment." 287

In evaluating a minor's "experience," the district court noted that "work experience, experience in living away from home, and handling personal finances" could be important to consider. ${ }^{288}$ "Perspective" is assessed with evidence demonstrating a minor's appreciation for the

283. Id. at 640 .

284. 639 F. Supp. 952 (1986).

285. Id.

286. UTAH CODE ANN. \$ 76-7-304(2) (1953).

To enable the physician to exercise his best medical judgment, he shall:

(3) $[\mathrm{N}]$ otify, if possible, the parents upon whom the abortion is to be performed, if she is a minor. . This statute was construed by the Utah Supreme Court as mandating notice where possible to the parents of minors seeking an abortion.

Id.

287. H.B., 639 F. Supp. at 954.

288. Id. 
gravity of her options (in the case of abortion). ${ }^{289}$ Moreover, the district court called for an examination of the minor's ability to consider short term and long term consequences as well as a realistic perception of the circumstances. ${ }^{290}$ "Judgment" questions the minor's ability to be "fully informed so as to be able to weigh alternatives independently and realistically." ${ }^{291}$ This characteristic also considers the minor's conduct including ignorance of assessing options and stress. ${ }^{292}$

In H.B. the district court's finding of facts considered both facts specific to the case as well as facts that may be considered general to all minors. ${ }^{293}$ The minor's marital status, age, whether emancipated, whether the minor lived at home with her parents, employment status and history, educational performance and status, and history, familial history, facts and circumstances surrounding the pregnancy and decision to abort, persons the minor consulted, and results from a variety of examinations including I.Q. ${ }^{294}$

State courts have also employed a similar analysis. Florida enacted a statute that requires a minor to prove by clear and convincing evidence that she is "sufficiently mature to decide whether to terminate her pregnancy." 295 The court is required to "hear evidence relating to the emotional development, maturity, intellect, and understanding of the minor, and all relevant evidence. ${ }^{296}$ Florida courts consider a variety of factors in assessing maturity. Such factors include the minor's physical age, work experience, proclivity to seek counsel and support from a trusted adult, awareness of her options other than abortion, employment status and history, educational performance and status, and life plans. ${ }^{297}$ The court is thereafter required to issue a written order with specific findings of fact and conclusions of law that support its

289. Id.

290. Id.

291. Id.

292. Id.

293. Id. at $955-58$.

294. Id.

295. FLA. STAT. $\$ 390.01114(4)(c)(2006)$.

296. Id.

297. In re Doe, 967 So.2d 1017, 1019 (Fla. Dist. Ct. App. 2007); In re Doe, 924 So.2d 935, 939 (Fla. Dist. Ct. App. 2006); In re Doe, 932 So.2d 278, 284 (Fla. 2d DCA 2005). 
decision. ${ }^{298}$ State courts across the country examine the "maturity" of a minor in much the same way. ${ }^{299}$

\section{Presumption of immaturity in juvenile transfer decisions.}

Juvenile transfer decisions are inconsistent with the common understanding and status of children in the legal domain. Statutory exclusions and automatic transfers presume maturity and permit the state to circumvent requirements set out in Kent guaranteeing a hearing prior to transfer as well as the assistance of counsel. Statutory exclusion and direct file expose juveniles to adult criminal prosecution without assessing common characteristics that most other courts evaluate prior to any adjudication involving a minor. Such characteristics include criminal history, but also psychosocial maturity and social history. ${ }^{300}$ Indeed, juvenile courts were created because of society's assumption that juveniles may be treated constitutionally distinct from adults. ${ }^{301}$ This recognition lies in the understanding that this different treatment is permissible because of a juvenile's lack of maturity.

The presumption of immaturity is a principle in juvenile law that transcends its substantive progeny. In cases where a juvenile is to be transferred to adult court for criminal prosecution, there should be prophylactic protecting of juveniles from entering the adult system where it is all but guaranteed that the juvenile will recidivate and become an adult criminal offender. The principle undergirding the presumption of immaturity used in juvenile transfer decisions is the same as was announced in Bellotti v. Baird: minors are incapable of making reasoned decisions.

The presumption of immaturity may be established by statute, especially in direct file and statutory exclusion jurisdictions. Such a presumption ought to be a rebuttable mandatory presumption. This

298. Id.

299. In re Anonymous, 8 So.3d 1004, 1005-06 (Ala. Civ. App. 2008) (assessing a minor's maturity and considering employment status and minor's lack of consultation with a trusted adult); In re Doe, 2008 WL 4681847, at *3 (Ohio Ct. App. 2008) (reviewing lower courts maturity determination and contemplating minor's age, work status, and educational performance).

300. Robert O. Dawson, fudicial Waiver Theory and Practice, in CHANGING BORDERS OF Juvenile Justice: Transfer of Adolescents To The Criminal CourT (Jeffrey Fagan \& Franklin E. Zimring eds., 2000).

301. Bellotti, 443 U.S. at 635. 
would require the court to presume that a minor is immature and less blameworthy upon a showing that the juvenile-defendant is under the age of eighteen. This requires that courts begin the criminal adjudication of a minor with the understanding that juvenile court is the proper forum because the juvenile is less blameworthy.

The prosecution would have to rebut the presumption by producing evidence tending to show the juvenile's maturity, and therefore he or she should be considered as criminally blameworthy as an adult. Such evidence that may be presented to establish maturity is informed by the minor abortion line of cases. This evidence would include whether the juvenile was emancipated, whether the juvenile has ever been adjudged "mature" in a previous legal proceeding, the juvenile's mental health status, I.Q., familial status, social service history, financial dependency, and criminal history. Experts should be called to attest to the psychosocial developmental characteristics of a juvenile generally, as well as the "maturity" level of the individual specifically. Furthermore, because the State has the burden of proof and persuasion in a criminal case, the Morgan theory of presumptions is the best fit. With this, the prosecutor will hold both the burden of production and persuasion. Moreover, the establishment of maturity ought to be made by clear and convincing evidence. This threshold inquiry will ensure that the review of the evidence is more probing, guaranteeing greater attention to the juvenile-defendants profile and characteristic tendencies. If the prosecutor meets her burden, the judge may determine that transfer is appropriate. However, if the prosecutor fails to show that the juvenile is "mature," the case will be adjudicated in juvenile court.

\section{B. Diminished Capacity as a Defense}

While the doctrine of diminished capacity is not the most well settled area of law, it does allow room for interpretation. There is no standard definition of diminished capacity. ${ }^{302}$ Many scholars and commentators consider the notion that diminished capacity as a defense is a "legal colloquialism." ${ }^{303}$ Instead, most consider diminished capacity

302. Henry F. Fradella, From Insanity to Diminished Capacity: Mental ILLNESS AND CRIMINAL EXCUSE IN CONTEMPORARY AMERICAN LAW 59 (2007).

303. Dressler, supra note 264, at 368 (quoting State v. Humanik, 489 A.2d 691, 697 (N.J. Super. Ct. App. Div. 1985)). 
as an evidence doctrine. ${ }^{304}$ In a criminal trial, a defendant introduces evidence for the purpose of demonstrating that he or she did not have the requisite intent required to be convicted of the charged offense. If the State has not adequately proven to the trier of fact that the defendant possessed the requisite mens rea element, the defendant is entitled to acquittal or mitigation of the original offense to a lesser included offense. The problems associated with invoking the doctrine are typically evidentiary as certain evidence is not admissible if the defendant failed to plead not guilty by reason of insanity. In using the mitigation model of juvenile justice and guided by Best Interest ideals, an argument can be made that diminished capacity may be used as a defense in adult criminal prosecutions of juveniles.

Scott and Steinberg's mitigation framework specifically examining the diminished capacity of adolescents may be used to demonstrate the way in which the defense may be utilized as a defense by a juvenile at trial in adult court. This would allow for mitigation of the original offense based on evidence presented to a jury regarding psychosocial and biological distinctions between juveniles and adults as well as evidence related to the "maturity" of the juvenile-defendant. Such testimony would be used to answer the "question of whether the defendant in fact possessed a particular mental state of the charged offense." 305 However, it is important to understand the context and complexities of diminished capacity in order to fully comprehend the manner in which the defense could possibly work.

It is important to note that a debate is forging ahead regarding the "capacity" of juveniles. Scott and Steinberg argue that adolescents possess a diminished capacity due to immaturity and impulsivity. ${ }^{306}$ For them, "youthful choices may share much in common with those of adults whose decision-making capacities are impaired by emotional disturbance ... or failure to understand fully the consequences of their acts." ${ }^{" 307}$ With this, Scott and Steinberg work within the parameters of traditional criminal law and established criminal defenses. Professor Jennifer Drobac challenges this framework by arguing that adolescents

304. Id.; FRADELLA, supra note 302, at 59-60.

305. United States v. Pohlot, 827 F.2d 889, 896 (3d Cir. 1987).

306. Scott \& Steinberg, supra note 4 , at 830.

307. Id. 
do not in fact possess a diminished capacity. ${ }^{308}$ Instead, she asserts that adolescents have a "developing capacity" because they are still developing and maturing into adults. ${ }^{309}$ Drobac's formulation of adolescent capacity captures the lesser criminal blameworthiness of adolescents that Scott and Steinberg recognize while simultaneously rejecting the traditional criminal law understanding of lesser capacity as a defense. While there is a great deal of merit in Drobac's capacity framework, for present purposes it is important to stay within the parameters of the traditional criminal prosecution in adult court and within the confines of already recognized criminal law defenses.

\section{Diminished capacity generally}

Diminished capacity typically refers to two classes of situations in which an individual's atypical mental state will either exonerate her or result in a conviction of a lesser included offense than was originally charged.$^{310}$ For purposes of this article, only the second category will be discussed. The understanding of diminished capacity in the second application mitigates or "partially excuses" the offenders guilt even if she possessed the requisite mens rea to commit the crime. ${ }^{311}$ With this, the defense of "partial responsibility" works in a practical sense similar to an evidentiary rule. ${ }^{312}$ The goal of the defense is to have such evidence admitted to demonstrate to the trier of fact that although the offender possessed the intent to commit the crime, she is only partially responsible because she is a juvenile. Such evidence would most likely be in the form of experts in the area of neuro-science and psychosocial studies, mental health experts, counselors, and the like. While such defenses have been used in American courts, only a few states permit the defense. ${ }^{313}$

American jurisdictions are divided over what type of evidence concerning mental abnormality should be admissible for the purpose of

308. Jennifer Ann Drobac, Sex and The Workplace: "Consenting” Adolescents and a Conflict of Laws, 79 WASH. L. REV. 471, 519 (2004).

309. Id.

310. Dressler, supra note 264, at 367.

311. Id. at 368 .

312. $I d$.

313. Id. 
mitigating mens rea outside of the insanity defense. Some jurisdictions only allow such evidence in murder prosecutions. ${ }^{314}$ These jurisdictions will allow the introduction of mens rea evidence related to insanity but will not admit it to show that a defendant lacked the capacity to form the requisite intent to be convicted of the crime charged. ${ }^{315}$ Others that follow the Model Penal Code permit such evidence so long as it goes to the complete negation of the mens rea element. ${ }^{316}$ Finally, some states permit the defense in the case of specific intent offenses. ${ }^{317}$ If the defense is permissible, it is generally only used in the context of homicide-reducing murder to manslaughter.

\section{Clark v. Arizona}

The United States Supreme Court recently considered a question on this matter. In Clark v. Arizona ${ }^{318}$ the Court considered whether it was constitutionally permissible to prohibit expert mental health evidence to disprove a mens rea element of the charged offense. ${ }^{319}$ In its opinion, the Court differentiated between three types of mens rea evidence: observational, mental disease, and capacity evidence. ${ }^{320}$ Observational evidence is testimony from witnesses who can describe a defendant's actions and words. ${ }^{321}$ It can also include testimony from an expert on a defendant's penchant to think or behave a certain way. ${ }^{322}$ Mental disease evidence concerns a diagnosis of the defendant with testimony concerning related characteristics of the diagnosed disease. ${ }^{323}$ Capacity evidence is testimony from an expert regarding the defendant's capacity to form the requisite intent necessary to be convicted of the charged offense. ${ }^{324}$ The law in Arizona permitted the de-

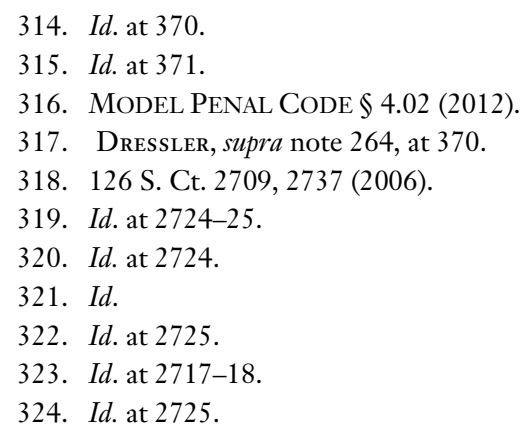


fendant to introduce observational evidence but prohibited mental disease and capacity evidence from being admitted. ${ }^{325}$ The Court concluded that Arizona was within its constitutional right to do so. ${ }^{326}$ The majority asserted that the state has the right to presume that people are sane and it was permissible for Arizona to place the burden of persuasion on the defendant to prove insanity as a defense. ${ }^{327}$ The Court reasoned that allowing the introduction of evidence which would create doubt on mens rea would in effect permit the defendant to rebut the presumption of sanity. ${ }^{328}$ With this, the Supreme Court upheld a State's right to restrict mental disease and capacity evidence in adult criminal prosecutions. ${ }^{329}$

\section{Application}

While it is clear that most American jurisdictions hesitate in permitting diminished capacity as a defense or severely restrict capacity evidence, diminished capacity may work in adult prosecutions of juveniles. It may work as a special defense for juveniles, thereby allowing the introduction of evidence of a juvenile's "immaturity" and if relevant, a juvenile's emotional or cognitive disabilities. Such evidence that may be introduced would relate to the same factors discussed in Section A regarding the presumption of immaturity, including whether the juvenile has ever been adjudged "mature" in a previous legal proceeding, the juvenile's mental health status, I.Q., familial status, social service history, financial dependency, and criminal history. Experts may be called to testify regarding the general psychosocial developmental characteristics of juveniles as well as the "maturity" level of the individual specifically.

Prior to the introduction of evidence of diminished capacity, a defendant would have to meet her burden of production by providing sufficient evidence of "immaturity," or in the case of children with disabilities, enough evidence of mental disease that would interfere with

\footnotetext{
325. Id.

326. Id. at 2737.

327. Id. at $2732-33$.

328. Id. at $2730-31$.

329. Id. at 2737.
} 
the defendant's ability to develop the requisite mens rea. Once the defendant meets this burden, the defendant's trial witnesses will testify that defendant's capacity to develop the required intent was "diminished" at the time the crime occurred. This would include the introduction of mental health professionals including psychologists, psychiatrists, counselors, social workers, and the like. If the fact-finder finds the juvenile immature then it may find that the juvenile had diminished capacity and therefore incapable of forming the requisite intent to commit the charged offense. However, the jury may only partially excuse the juvenile-defendant and mitigate the charged offense to a lesser included offense.

Different courts have permitted the admissibility of a variety of evidence to support a defendant's diminished capacity claim. For example, the Third Circuit Court of Appeals has held that evidence concerning volitional impairment (impulse control) is evidence of diminished capacity. ${ }^{330}$ Thus, it is likely that the court will allow evidence of the juvenile's adolescent development and psychosocial status. Such testimony would present the fact-finder with evidence of a "normal" adolescent response versus the response of the defendant. Permitting such evidence related to a juvenile's capacity to form the requisite mens rea would recognize the very real difference between a juvenile and an adult. The fact-finder would ultimately decide if the defendant acted as a juvenile or an adult.

With the criticism and uncertainty surrounding diminished capacity as a defense, it may be difficult to persuade legislators to permit the use of capacity evidence in adult prosecutions of youth. However, if Best Interest considerations are the foundation of the juvenile justice, allowing this defense appears to be an appropriate compromise between those who wish to prosecute juveniles as adults and those who desire juveniles to be treated differently than adults. Legislators may also want to consider extending this defense to crimes other than homicide in those prosecutions concerning juveniles.

330. United States v. McBroom, 124 F.3d 533, 47-48 (3d Cir. 1997). 


\section{Extreme Mental or Emotional Disturbance}

The Model Penal Code ("MPC") approach to partial responsibility in the context of homicide provides guidance on the way in which neuroscience and psychosocial evidence could be used to mitigate a juvenile's criminal responsibility. The mitigating defense of "extreme mental or emotional disturbance" ("EMED") permits a defendant to utilize this defense to mitigate a charge of murder to manslaughter generally. Some states that have adopted this formulation of homicide, such as New York, permit the state to charge manslaughter committed with EMED, ${ }^{331}$ as well as use EMED as an affirmative defense. ${ }^{332}$ In this section, the use of EMED as a defense in adult prosecutions of juveniles is explored.

\section{EMED generally}

Under the Model Penal Code, a homicide that is committed as the product of "extreme mental or emotional disturbance for which there is a reasonable explanation" constitutes manslaughter as opposed to murder. ${ }^{333}$ The EMED defense has two main components: 1) it codifies the common law "sudden heat of passion" principle and 2) it allows courts to consider partial responsibility as a defense. ${ }^{334}$ The standard of "reasonableness" for the actor's conduct is "determined from the viewpoint of a person in the actor's situation under the circumstances as he believes them to be." ${ }^{35}$ The American Law Institute explained the operation of partial responsibility as,

[L]ook[ing] into the actor's mind to see whether he should be judged by a lesser standard than that applicable to ordinary men. It recognizes the defendant's own mental disorder or emotional instability as a basis for partially excusing his conduct ... To the extent that the abnormal individual is judged as if he were normal, to the extent that the drunk man is judged as if he were sober, to the extent, in short,

331. N.Y. PENAL LaW $\$ 125.20$ (McKinney 2009).

332. N.Y. PENAL LAW $\$ 125.27$ (2)(a) (McKinney 2009).

333. Model Penal Code $\$ 210.3(1)$ (b) (2012).

334. Dressler, supra note 264, at 375 .

335. Model Penal Code $\$ 210.3(1)(b)$ (2012). 
that the defective person is judged as if he were someone else, the moral judgment of the victim is undermined. ${ }^{336}$

By specifically recognizing partial responsibility as a defense, the American Law Institute explicitly recognized individual character defects to be taken into consideration even if just partially. To ignore such deficiencies is to undermine the normative judgment of the court and community.

\section{Application}

In trying juveniles as adults, certainly the courts could consider the psychosocial and emotional infirmities ever present in adolescent development. While EMED is traditionally used only in the context of homicide, this is not to say that the reasonableness standard could not be transported to a variety of cases that involve a juvenile transferred to adult court. By using both a subjective and objective standard, the trier of fact would be permitted to consider the frailties inherent in adolescents, including immaturity and the characteristics associated with this, when determining the more specific issue of "whether there is a reasonable explanation or excuse for the defendant's EMED that caused him to take a life." Therefore, if the trier of fact finds that there was a reasonable explanation for the juvenile-defendant's emotional disturbance, based on D's psychological characteristics that caused him to commit the crime then the juvenile-defendant is convicted of a lesser charge ${ }^{337}$ By taking into consideration psychosocial factors, factfinders are permitted to adjudicate the offense with the youth's psychosocial and biological characteristics in mind. Using this formulation to evaluate reasonableness when juveniles are tried in adult court will allow juries to take into consideration characteristics specific to juveniles while simultaneously maintaining the "ordinary person" standard.

336. Id. $\$ 210.3$, cmt. at $71-72$.

337. DRESSLER, supra note 264, at 376. 


\section{Limitations}

Professor Stephen Morse once called for the abolition of the defense. At the time, Morse posited that society did not impose upon individuals high moral standards. ${ }^{338}$ All it requires is that we do not commit serious offenses. ${ }^{339}$ Even considering mental health infirmities, Morse would not consider "differences in background, mental or emotional condition, or other factors often thought to necessitate mitigation." ${ }^{340}$ Morse's premise presumes that it is relatively easy not to break the law. However, it is harder for some than others especially when considering recent research on policing practices, poverty, and race. ${ }^{341}$ Thus, Morse's principle fails to take into account the realities of criminal investigation and criminal prosecution. Professor Morse now "proposes that the criminal law ... include a generic, doctrinal mitigating excuse of partial responsibility that would apply to all crimes ...."."342

Many have also argued that the partial responsibility is a doubleedged sword. While the defense serves to mitigate the criminal blameworthiness of the defendant by permitting consideration of mental abnormality, it is this defect that exacerbates his dangerousness. ${ }^{343}$ This argument may be meritorious in the context of adult dangerous offenders, but it is less salient when applied to juvenile offenders. The "Best Interest of the Child" standard considers the youth offender amenable to reform as she is malleable and still developing both biologically and psychosocially.

338. Stephen Morse, Undiminished Confusion in Diminished Capacity, 75 J. CRIM. L. \& CRIMINOLOGY 1, 30 (1984).

339. $I d$.

340. Id.

341. Id.

342. Stephen J. Morse, Diminished Rationality, Diminished Responsibility, 1 OHIO ST. J. CRIM. L. 289, 289 (2003).

343. Peter Arenella, The Diminished Capacity and Diminished Responsibility Defenses: Two Children of a Dooned Marriage, 77 COLUM. L. REv. 827, 857 (1977). 


\section{Conclusion}

The Best Interest ideals of the late nineteenth century carry with them lessons and principles that are applicable today and may be further utilized in the adult criminal prosecution of juveniles. Understanding that juveniles are capable of change and are inherently different than adults is the first step to creating appropriate safeguards for juveniles as well as society. This paper is not meant to argue that juveniles should not be punished for their crimes. Instead, the objective of this article is to recognize differences between juveniles and adults so as to craft statutory protections in transfer decisions as well as begin to think about the way in which traditional criminal law defenses may be utilized during the trial of a juvenile adjudicated in adult court.

The presumption of immaturity, diminished capacity, and EMED are presently used by hundreds of courts and attorneys in the United States on a day to day basis. These legal tools are not without limitation and critique. The presumption of immaturity is thought to be open to too much subjectivity and discretion. Moreover, the "maturity" characteristic in one juvenile may be different in another. There is no uniform methodology to measure "maturity." Diminished capacity is not the most popular defense to be used in a criminal trial and appears to be losing much of its luster in the way of Clark. EMED, currently only used in homicide cases, is unlikely to be extended to a defense for juveniles in adult criminal court. Nevertheless, these ideas promote mitigation and recognize the difference between juveniles and adults. More importantly, these legal tools permit a fact-finder to consider the inherent distinctions between the two groups at the most critical point in one's life: criminal proceedings where the deprivation of liberty is a real risk.

This article advocates for the resurrection of Best Interest ideals in today's juvenile justice system. New theories and ideas are developing every day in this arena. However, Best Interest remains the strongest principle in the administration of juvenile justice and juvenile law generally. It is the bedrock principle of the juvenile court system and is still recognized in the new millennium. Instead of abandoning Best Interest and promoting retribution, legislators need realize the scientific distinctions and the Supreme Court adoption of the differences between juvenile criminal responsibility and adult blameworthiness. This 
should serve as a catalyst to overhaul retributivist juvenile systems in America. In the meantime, advocates and practitioners ought to consider creative ways to interject Best Interest through mitigation type vehicles. 